
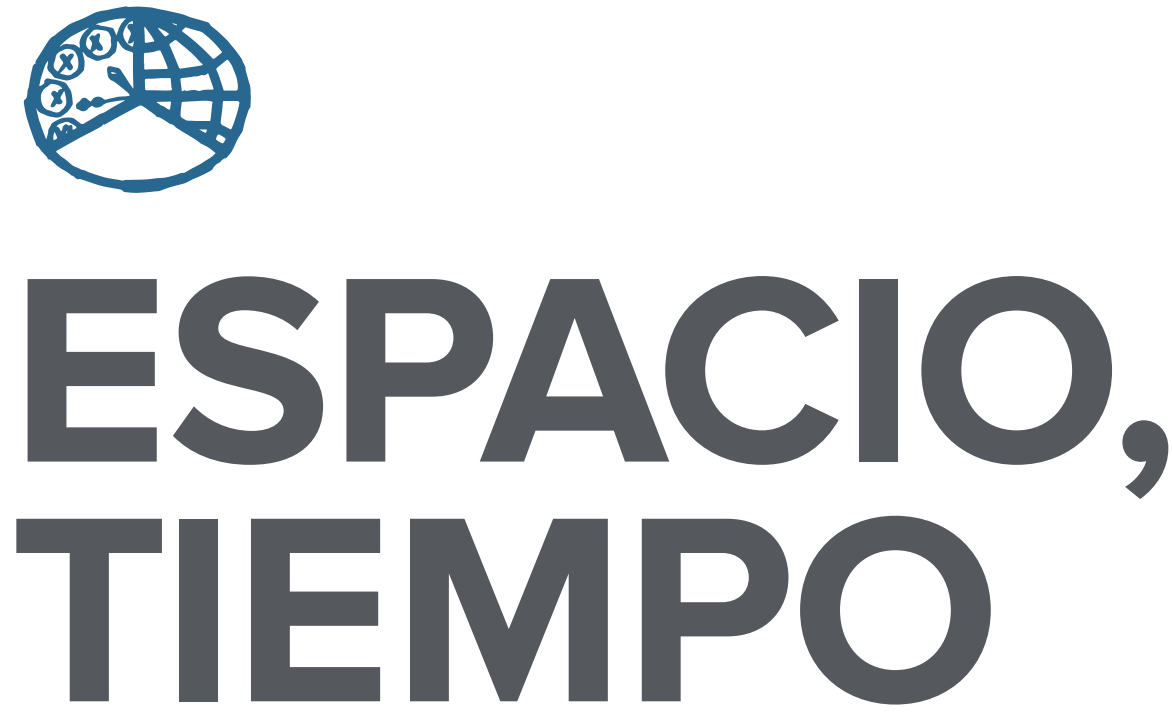

AÑO 2014

NUEVA ÉPOCA

ISSN 1130-4715

E-ISSN 2340-1478
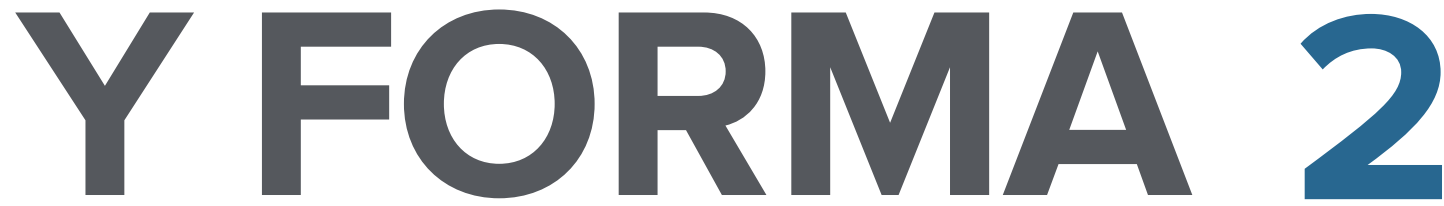

SERIE VII HISTORIA DEL ARTE

REVISTA DE LA FACULTAD DE GEOGRAFÍA E HISTORIA 

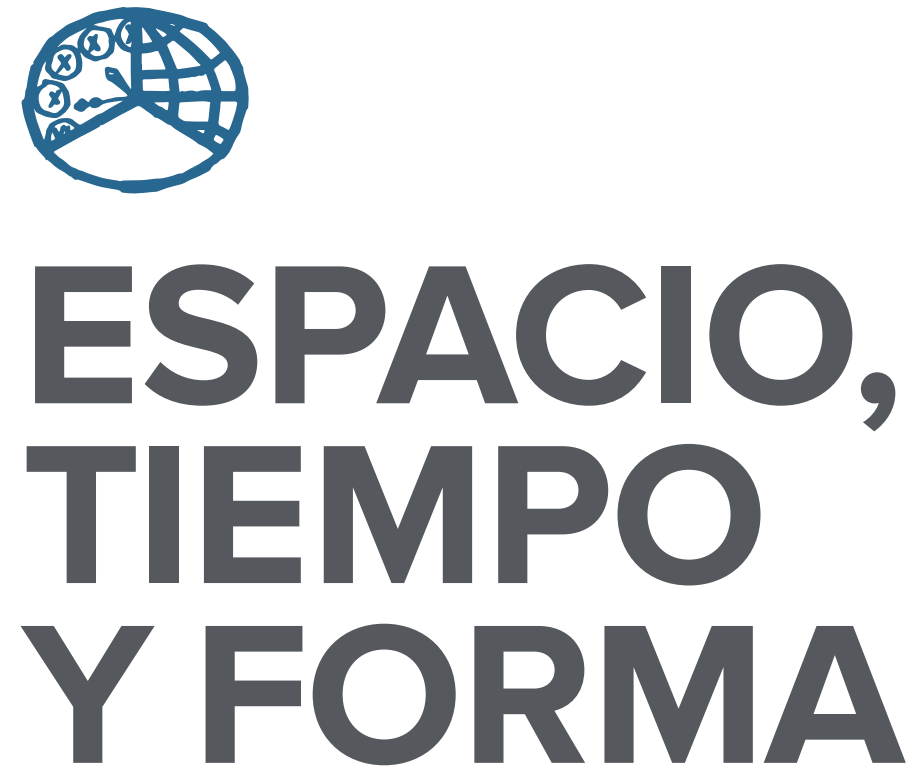

AÑO 2014

NUEVA ÉPOCA

ISSN $1130-4715$

E-ISSN 2340-1478

SERIE VII HISTORIA DEL ARTE

REVISTA DE LA FACULTAD DE GEOGRAFÍA E HISTORIA

http://dx.doi.org/10.5944/etfvii.2.2014

\section{UกED}

UNIVERSIDAD NACIONAL DE EDUCACIÓN A DISTANCIA 
La revista Espacio, Tiempo y Forma (siglas recomendadas: ETF), de la Facultad de Geografía e Historia de la UNED, que inició su publicación el año 1988, está organizada de la siguiente forma:

$$
\begin{aligned}
& \text { SERIE I - Prehistoria y Arqueología } \\
& \text { SERIE II - Historia Antigua } \\
& \text { SERIE III - Historia Medieval } \\
& \text { SERIE IV - Historia Moderna } \\
& \text { SERIE V - Historia Contemporánea } \\
& \text { SERIE VI - Geografía } \\
& \text { SERIE VII - Historia del Arte }
\end{aligned}
$$

Excepcionalmente, algunos volúmenes del año 1988 atienden a la siguiente numeración:

$$
\begin{aligned}
& \mathrm{N} .^{\circ} 1 \text { - Historia Contemporánea } \\
& \mathrm{N}^{\circ} 2 \text { - Historia del Arte } \\
& \text { N. }{ }^{\circ} 3 \text { - Geografía } \\
& \text { N. }{ }^{\circ} 4 \text { - Historia Moderna }
\end{aligned}
$$

ETF no se solidariza necesariamente con las opiniones expresadas por los autores.

Espacio, Tiempo y Forma, Serie vII está registrada e indexada, entre otros, por los siguientes Repertorios Bibliográficos y Bases de Datos: DICE, ISOC (CINDOC), RESH, IN-RECH, Dialnet, e-sPacio, UNED, CIRC, MIAR, FRANCIS, PIO, ULRICH'S, SUDOC, 2DB, ERIH (ESF).

\author{
UNIVERSIDAD NACIONAL DE EDUCACIÓN A DISTANCIA \\ Madrid, 2014 \\ SERIE VII · HISTORIA DEL ARTE (NUEVA ÉPOCA) N. ${ }^{\circ} 2,2014$ \\ ISSN $1130-4715 \cdot$ E-ISSN 2340-1478 \\ DEPÓSITO LEGAL \\ M-21.037-1988 \\ URL \\ ETF VII · HISTORIA DEL ARTE · http://revistas.uned.es/index.php/ETFVII \\ DISEÑO Y COMPOSICIÓN \\ Ángela Gómez Perea · http://angelagomezperea.com \\ Sandra Romano Martín · http://sandraromano.es \\ Impreso en España · Printed in Spain
}

(c) (1) (8) Esta obra está bajo una licencia Creative Commons

Reconocimiento-NoComercial 4.0 Internacional. 


\title{
PODER, HUMANISMO Y RELIGIOSIDAD \\ EN TIEMPOS DEL PATRIARCA \\ JUAN DE RIBERA EN VALENCIA: \\ SU COLECCIÓN DE ESCULTURA CLÁSICA
}

\author{
POWER, HUMANISM AND RELIGIOSITY \\ AT THE TIME OF THE PATRIARCH \\ JUAN DE RIBERA IN VALENCIA: \\ HIS COLLECTION OF CLASSICAL SCULPTURE
}

\author{
David Gimilio Sanz ${ }^{1}$ \\ Recibido: 28/11/2013 - Aceptado: 11/03/2014 \\ http://dx.doi.org/10.5944/etfvii.2.2014.13782
}

\begin{abstract}
Resumen
El artículo pretende dar a conocer la colección de escultura antigua que poseía Juan de Ribera, arzobispo de Valencia, influido por su formación humanista en la Casa de Pilatos de Sevilla y por su relación con su padre Per Afan de Ribera, duque de Alcalá y virrey de Nápoles. Se aporta documentación inédita sobre esculturas compradas en Nápoles y se contrasta con las piezas inventariadas en sus palacios tras su fallecimiento en I6II, donde existían hasta dos series de bustos de emperadores. Además, se puede observar la evolución estética de Juan de Ribera, desde los postulados humanistas hasta la influencia de Trento y de los textos del cardenal Palleoti sobre la visión de las imágenes sacras.
\end{abstract}

\section{Palabras clave}

Humanismo; duque de Alcalá; San Juan de Ribera; escultura antigua; Pozzuoli; Hércules

\section{Abstract}

The aim of the article is to divulge the ancient sculpture collection owned by Juan de Ribera, Archbishop of Valencia, influenced by his humanist training at the House of Pilate in Seville and his relationship with his father Per Afan de Ribera, Duke of Alcalá and Viceroy of Naples. Unpublished documentation regarding sculptures purchased in Naples is attached and it is contrasted with the inventoried pieces at their palaces after his death in I6II, where there were up to two series of busts of emperors. In addition, we will trace the aesthetic evolution of Juan de Ribera, from

1. Técnico de Arte Valenciano, Museo de Bellas Artes de Valencia. E-mail: gimilio_dav@gva.es 
humanistic principles to the influence of Trent and texts of Cardinal Palleoti about the vision of sacred images, can be observed.

Keywords

Humanism; Duke of Alcalá; Saint Juan of Ribera; ancient sculpture; Pozzuoli; Hercules

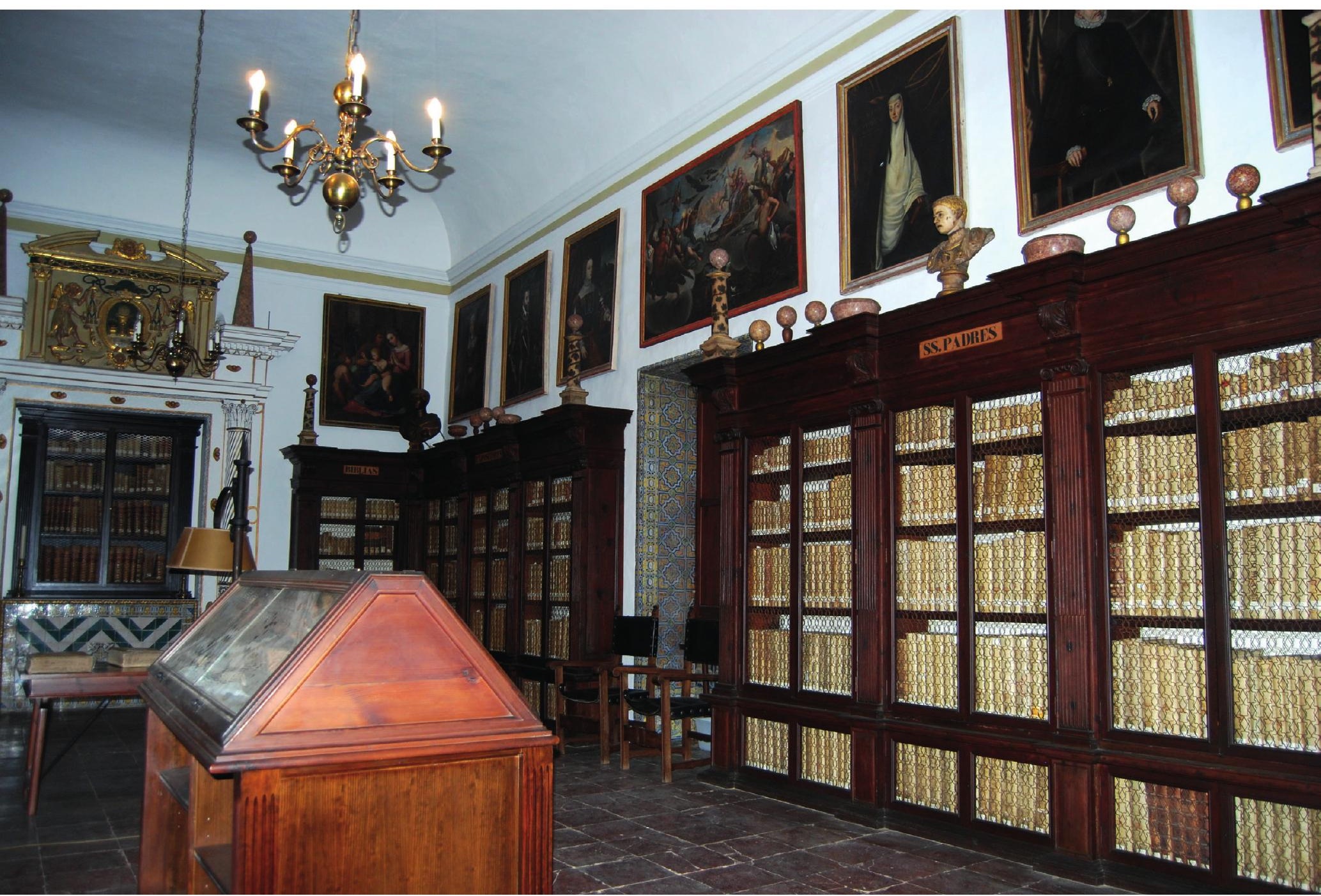

FIGURA 1. VISTA GENERAL DE LA BIBLIOTECA DE SAN JUAN DE RIBERA

Real Colegio de Corpus Christi de Valencia. Todas las imágenes han sido realizadas por el autor. 


\section{INTRODUCCIÓN}

La figura del Patriarca Juan de Ribera (I532-I6II) continua siendo de gran trascendencia para los historiadores por su vertiente política, al ostentar el poder desde diferentes cargos políticos y religiosos que le permitió controlar e influir en la sociedad de su época, y por su vertiente espiritual, puesto que asimiló las doctrinas tridentinas y un nuevo espiritualismo contrarreformista que influyeron en la sociedad y en la cultura valenciana, superando el humanismo cristiano de corte renacentista para crear un cristianismo humano donde la santidad y la religión fuesen el centro de la vida pública y privada ${ }^{2}$. Vinculado a este ámbito destaca la fundación del Real Colegio y Seminario de Corpus Christi desde donde resulta innegable su papel de gran mecenas con un excepcional legado cultural y artístico3.

El coleccionismo pictórico del Patriarca Ribera ha sido tratado en diferentes ocasiones de manera profusa y exitosa ${ }^{4}$. El indiscutible valor de obras de Luis de Morales, Dirk Bouts, Giovanni Baglione, Mabuse, El Greco, Stradanus, Federico Zuccaro, Antonio Ricci y las pinturas murales del pintor italiano Bartolomé Matarana, a las que se añaden las pinturas de los artistas locales como Francisco Ribalta y Juan Sariñena, permiten considerar su colección pictórica como una de las más interesantes y decisivas para la historia del arte hispano. Falomir en una reciente publicación ofrece una visión más ajustada sobre la pintura contrarreformista en la Valencia del Patriarca, así como intenta vincular dos conceptos tradicionalmente separados en la historiografía: el decoro y el goce estético en la pintura de la época, insertando al Patriarca en un contexto supra-nacional5.

Sin embargo, apenas nada se ha escrito sobre la escultura, seguramente por el apurado número de piezas, frente a la pintura, y por la aparente escasa relevancia de las mismas, más allá de algunas obras que, por su significación devocional y artística, han sido ampliamente estudiadas como el Cristo crucificado del altar mayor donado por doña Margarita de Cardona y su esposo Adam de Diatristan o la Inmaculada de Gregorio Fernández donada por los condes de Castro, don Gómez Manrique de Mendoza y doña María Enríquez de Ribera, sobrina del fundador, en I639 al Real Colegio y que escapa de la colección del Patriarca propiamente dicha. El mismo Fernando Benito zanja la colección escultórica de la siguiente manera:

2. Los días 26, 27 y 28 de enero de 2011 se celebró un Congreso Internacional sobre el Patriarca Ribera y su tiempo que sin duda ofrece nuevas y sugerentes perspectivas. Las actas recogen cuarenta y un estudios de historiadores prestigiosos y especialistas en la época y en la figura del Patriarca con el título El Patriarca Ribera y su tiempo. Religión, cultura y política en la Edad Moderna. Valencia, Institució Alfons el Magnànim/Diputación Valencia, 2012.

3. Aprovechando el IV centenario de la muerte de San Juan de Ribera se ha realizado una exposición coordinada por el director conservador del museo, Benito Goerlich, Daniel: Pastor Sanctus Virtutis Cultor. El legado del Patriarca Juan de Ribera. Valencia, 2011. Agradezco a Daniel Benito sus facilidades para acceder a todos los recovecos del Colegio en cualquier momento, así como su larga y sincera amistad.

4. Benito Doménech, Fernando: Pinturas y pintores en el Real Colegio de Corpus Christi. Valencia, 1980. El autor siguió tratando esta excepcional pinacoteca en otros artículos y publicaciones como BENITO DOMÉNECH, Fernando: Pintura europea en las colecciones valencianas. Valencia, Museo de Bellas Artes de Valencia, 26 de mayo-29 de agosto de 1999. Valencia, 1999.

5. FALOMIR, Miguel: «El Patriarca Ribera y la pintura: Devoción, persuasión e historia», Actas de las Jornadas Una religiosa urbanidad. San Juan de Ribera y el Colegio del Patriarca en la Cultura artística de su Tiempo. Valencia, 2013, pp. 103-116. 
Las colecciones del arzobispo Ribera se componían principalmente de esculturas y pinturas. Las primeras no fueron muy numerosas y entre ellas se detectan bustos de emperadores, santos y unas pocas figuras mitológicas, además de multitud de bolas de jaspes de colores diferentes, que sencillamente serían coleccionadas como curiosidades mineralógicas ${ }^{6}$ (FIGURA 1)

El conjunto escultórico que abarca el presente estudio está formado por el grupo de bustos de mármol, bronce y piedra con un aparente resabio clásico, junto a obeliscos, columnas, vasos y bolas de mármol de carácter ornamental, localizados todos ellos en la biblioteca del Patriarca, junto a las otras esculturas que se encuentran dispersas por el Colegio: una escultura de tamaño mediano de Hércules con un acusado contraposto y con sus habituales elementos iconográficos, localizada sobre la portada de ingreso a la biblioteca; una estatua de bronce de un sátiro o fauno ubicada sobre el vano que comunica el primer piso del claustro con la escalera de la biblioteca; la escultura llamada la palletera que quizás sea la más conoci$\mathrm{da}$, puesto que durante siglos estuvo en el claustro hasta que fue sustituida por la estatua sedente del Patriarca, obra de Mariano Benlliure; y por último, una fuente de mármol con un escudo nobiliario, despiezada y que estuvo montada años atrás tal y como muestra una fotografía antigua (una pieza, que por otra parte escapa al conjunto escultórico propiamente dicho, pero que requiere también de un estudio pormenorizado).

La escasa consistencia de la colección apenas sería objeto de estudio de no ser por dos elementos más. El primero es la documentación inédita, localizada en el archivo del Real Colegio, que respalda parte de este conjunto y resulta especialmente reveladora por el gusto erudito que el Patriarca tenía por las esculturas de la Antigüedad. Este conjunto documental está formado por tres documentos complementarios entre sí, que tienen como título Memorias de los mármoles y piedras que están en Cartagena de la disposición del Duque don Perafán que se trajeron de Nápoles y se han vendido al Patriarca ${ }^{7}$. Los dos primeros están redactados por don Bernardino de Escalante, notario que ejecutó algunas de las clausulas testamentarias de don Per Afán, y que son entregados a don Miguel Crespo, criado del Patriarca, para la supervisión y control de las piezas. Ambos textos se citan mutuamente; el primero es un listado de las cajas numeradas con la descripción de las piezas escultóricas y arquitectónicas, el segundo, son las instrucciones que don Miguel Crespo debe saber para la recuperación de las piezas y su traslado a Valencia. El tercer documento es un listado de las piezas que se entregan a don Miguel Crespo ${ }^{8}$. Ningún documento

\footnotetext{
6. Benito Doménech, Fernando: Pinturas y pintores... p. 30.

7. Archivo de Corpus Christi de Valencia (ACCV), fondo interno, LE 3.1. Agradezco la inestimable ayuda y colaboración de los archiveros de esta institución: Vicente España y Salvador Ferrando Palomares.

8. Las piezas, almacenadas en cajas, estuvieron custodiadas en la Casa de las Municiones del Rey en el puerto de Cartagena, a la espera de ser recogidas por don Miguel Crespo. La designación del puerto de Cartagena y no los de Valencia o Alicante de mayor calado y sobre todo más cercanos al lugar de destino, se debe a que aquel fue potenciado durante los reinados de Carlos I y de Felipe II en un intento de convertirlo en el nexo de unión del nuevo eje geoestratégico Andalucía-Italia.
} 
aparece fechado, pero se pueden datar hacia 157I, fecha del fallecimiento de Per Afán de Ribera, ya que esta venta se encuentra entre sus disposiciones testamentarias.

El segundo punto es el inventario post-mortem de Juan de Ribera de I6II, redactado por los albaceas que inventariaron exhaustivamente todas sus pertenencias en los tres palacios donde habitó: el arzobispal, el del Huerto del camino de Alboraya, y el del palacio de Burjassot, y que constata documentalmente la gran colección escultórica y ornamental que poseía ${ }^{9}$. En este documento se describen las diferentes estancias con todo su mobiliario y objetos suntuarios: bufetes de maderas nobles, tapices historiados, jarrones de jaspe con pies de bronce, pilas de mármol, pinturas alegóricas, retratos de monarcas, ramilletes de flores de bronce, porcelanas de Portugal, vajillas de vidrio de Barcelona, esculturas antiguas de faunos y sátiros, y hasta dos juegos de bustos de emperadores. Es decir, todo aquello que magnificaba la imagen de prestigio y potestas de Juan de Ribera, como arzobispo y virrey de Valencia, pero también de humanista e intelectual a los ojos de las visitas más selectas.

Esta galería de esculturas de corte renacentista de Juan de Ribera responde a un interés humanista por el mundo antiguo y por las artes a la italiana, única en el ámbito valenciano, en la misma línea que experimentó en el ámbito pictórico y arquitectónico, y que está en el mismo ambiente que la de los escasos coleccionistas hispanos de escultura de gran significación en su época. Será el profesor Morán Turina el que realice un exhaustivo estudio sobre los principales coleccionistas de escultura antigua en el territorio hispánico, el por qué de este tipo de coleccionismo y su diferenciación con el atesoramiento de antigüedades especialmente inscripciones, monedas y medallas ${ }^{\mathrm{IO}}$. De este reducido y selecto grupo de coleccionistas, Morán Turina menciona, recogiendo el Tratado de las Antigüedades de la memorable Peña de Martos (1590) de Diego de Villalta, a don Diego Hurtado de Mendoza, don Luis de Ávila y al duque de Alcalá. A este restringido grupo se han de sumar las colecciones reales de Felipe II, pese al escaso interés de éste por la escultura antigua romana y pagana ${ }^{\mathrm{II}}$, la del príncipe $\operatorname{Carlos}^{\mathrm{I2}}$ y de María de Hungría, tía del rey; así como las diferentes personalidades que la historiografía se ha encargado de sacar a la luz como el virrey de Nápoles don Pedro de Toledo y los duques de Luna y de Villahermosa. Algo similar realiza Luis Arciniega en el ámbito valenciano al revisar las fuentes históricas de Beuter, Viciana, Escolano..., la recuperación de los vestigios históricos y el enfrentamiento entre las dos posturas ideológicas y culturales, que tienen su máximo exponente en el enfrentamiento intelectual entre el rector

9. ACCV, fondo interno, LE 1.1. Sobre las otras casas que Juan de Ribera tuvo en Alfara, Puzol o Villar, su uso debió ser muy esporádico y sobre todo se sabe bien poco en cuanto a posibles aspectos artísticos ya que la documentación apenas las menciona. Benito DOMÉNECH, Fernando: Pintura y pintores... p. 22.

10. Morán Turina, Miguel: La memoria de las Piedras. Anticuarios, arqueólogos y coleccionistas en la España de los Austrias. Madrid, 2010.

11. Morán Turina, Miguel: «Arqueología y coleccionismo de antigüedades en la corte de Felipe ı» en Adán y Eva en Aranjuez. Investigaciones sobre la escultura en la Casa de Austria. Madrid, Museo del Prado, 1992, pp. 35-47.

12. COPpel, Rosario: «La colección de escultura del príncipe don Carlos (1545-1568)», Actas del simposio «El Coleccionismo de la Escultura Clásica en España». Madrid, Museo Nacional del Prado, 21 y 22 de mayo de 2001, Madrid, 2001, pp. 61-87. 
y teólogo Juan de Celaya y el filósofo Pedro Juan Nuñez que nos permite enmarcar de manera más cercana este proceso de la memoria histórica ${ }^{13}$.

El coleccionismo de escultura antigua en España es visto hoy en día, por tanto, como un coleccionismo más selecto y erudito que el de la pintura y supone la más alta cota en el coleccionismo de la anticuaria, por encima de las inscripciones, medallas y monedas cuyo atesoramiento respondía a un intento por preservar la progresiva pérdida de este tipo de vestigios. La escultura antigua, por tanto, suponía un encuentro con la cultura humanista y en cierta manera pagana, de corte renacentista y de origen italiano, distanciado de nuestro renacimiento más periférico. La sensibilidad y el tono intelectual de algunas de las colecciones atesoradas durante la permanencia en tierras italianas por este reducido grupo de coleccionistas superaban de forma sublime el tradicional gabinete de antigüedades que los humanistas españoles estaban acostumbrados a recopilar con un interés meramente arqueológico, al margen del puramente crematístico, para verificar las descripciones de los textos latinos en territorios hispánicos como evidencian los escritos sobre la Antigüedad de Arias Montano, Antonio Agustín, Ambrosio de Morales, Páez de Castro, Jerónimo Zurita, etc. ${ }^{\text {I4 }}$.

\section{DON PER AFÁN ENRÍQUEZ DE RIBERA, I DUQUE DE ALCALÁ, VIRREY DE NÁPOLES Y PADRE DE JUAN DE RIBERA}

El primer dato relevante que aparece en el documento Memorias de los mármoles... es el nombre del propietario original de la colección de escultura, don Per Afán de Ribera, que no es otro que el i duque de Alcalá, virrey de Nápoles y padre del Patriarca. Un dato que fue recogido en una de las primeras biografías de Juan de Ribera escrita por Francisco Escrivá en I6I2 con motivo del inicio del proceso de su beatificación ${ }^{15}$, pero que ha sido soslayado, casi silenciado, si no olvidado por el resto de la bibliografía.

Don Per Afán Enríquez de Ribera (Sevilla, I509-Nápoles, I57I), perteneciente al linaje de los Ribera (Adelantados Mayores de Andalucía), I duque de Alcalá de los Gazules, vi conde de los Molares y il marqués de Tarifa, fue uno de los grandes nobles de la corona de Castilla ${ }^{16}$. Además, fue nombrado virrey de Cataluña (I554-I558) y de Nápoles (I559-I57I). De su matrimonio con Leonor Ponce de León no tuvo descendencia, sin embargo sí que engendró hijos naturales, concretamente, con Teresa Pinelo, tuvo un vástago, Juan de Ribera, arzobispo de Valencia, virrey del reino de Valencia y patriarca de Antioquía; y con Luisa Mosquera y Esquivel tuvo una hija, Catalina que por matrimonio llegó a ser condesa de Malpica. Muerto Per Afán de

13. Arciniega García, Luis: «Miradas curiosas, temerosas e intencionadas a los vestigios del pasado en la Valencia de la Edad Moderna», Cuadernos Ars Longa, 3, Valencia, Universitat de València, 2013, pp. 61-94.

14. Morán y Turina, Miguel: Arqueología y coleccionismo... pp. 42-43.

15. Escrivá, Francisco: Vida del ilustrísimo y Excelentísimo señor don Juan de Ribera, Patriarca de Antioquía y Arzobispo de Valencia. Valencia, 1612.

16. Ladero Quesada, M.A.: «De Per Afán a Catalina de Ribera. Siglo y medio en la historia de un linaje sevillano (1371-1514)», Los Señores de Andalucía. Cádiz, 1998, 447-497. 
Ribera en Nápoles fue enterrado en la cartuja de Sevilla y su hermano Fernando le sucedió en sus títulos nobiliarios.

Sin embargo, parte de la fama del I duque de Alcalá, título otorgado por el rey Felipe Il en I558, se debe a la extraordinaria colección de esculturas de la Antigüedad que reunió durante su estancia en Nápoles como virrey y que finalmente mandó a su palacio sevillano, conocido hoy como la Casa de Pilatos. En esta colección escultórica están representados todos los géneros de la escultura antigua, así como también de la escultura moderna que sigue los modelos antiguos: relieves históricos y mitológicos, escultura ideal y retratos romanos desde Rómulo, el fundador de Roma, hasta el emperador Carlos v, el fundador del nuevo imperio dentro del concepto de continuidad histórica. Además, Per Afán de Ribera encargó al escultor Giuliano Menichini la restauración de las piezas y al arquitecto Benvenuto Tortello la disposición y exhibición de las esculturas en su palacio hispalense ${ }^{17}$. En definitiva, se trata de un conjunto de esculturas, en su mayoría antiguas, reunidas en Nápoles entre 1558, 1559 y I57I, fruto de un entorno humanista y erudito ${ }^{18}$, de obligada referencia para la arqueología, la historia del arte y la literatura del coleccionismo como ejemplo de supervivencia, que en otros casos de colecciones contemporáneas a ésta, o bien se han perdido o sólo han quedado como meras descripciones en los libros de viaje para la posteridad.

La magnitud política y cultural de la personalidad del I duque de Alcalá ocultó la relación paterno filial, que fue especialmente intensa y de gran responsabilidad paterna a lo largo de su vida, aunque fuera en la distancia y en formato epistolar ${ }^{19}$. Él fue el que designó la universidad de Salamanca como centro educativo donde Juan de Ribera cursó sus estudios de teología, siendo discípulo de Pedro de Sotomayor, Domingo de Soto, Gil de Nava y Melchor Cano y donde se codeó con los principales hijos de nobles castellanos. Él fue el que le propuso ampliar estudios en una universidad extranjera (a elegir entre Padua o Lovaina), ofrecimiento que rechazó su hijo prefiriendo Salamanca. Él fue el que intervino en los nombramientos como obispo, primero de Badajoz (1562-1568) y después como arzobispo de Valencia (I569-I6II), dada su relación con el Papa Pío iv y con el rey Felipe II. Ambos, padre e hijo, mantuvieron una rica correspondencia, si bien apenas quedan restos de ella en el archivo del Real Colegio, una documentación epistolar donde suponemos que existirían abundantes consejos sobre política, diplomacia y arte, pero también de preocupaciones vitales. Para ejemplificar esta relación hay que ver la decisión testamentaria del duque de ejecutar la construcción y dotación del convento de Corpus Christi en Bornos (Cádiz) a cargo de su hijo Juan de Ribera, proceso que este

17. Lleó Cañal, Vicente: La Casa de Pilatos. Madrid, 1998. Trunk, Markus: «La colección de esculturas antiguas del primer duque de Alcalá de la Casa de Pilatos de Sevilla», Actas del simposio El Coleccionismo de la Escultura Clásica en España. Madrid, Museo Nacional del Prado, 21 y 22 de mayo de 2001, Madrid, 2001, pp. 89-100.

18. «El núcleo más íntimo de este círculo cultural estaba constituido por el marqués de Santo Lucido, Ferrante Carrafa, y el duque de Seminara, aunque también participaban Scipione Ammirato, Bernardino Rota, Anello Paolino, Giovan Battista Attendolo y Alessandro d'Andrea. Méndez Rodríguez, Luis: Velázquez y la cultura sevillana. Sevilla, Universidad de Sevilla Fundación Focus-Abengoa, 2005, p.237.

19. Robres Lluch, Ramón: San Juan de Ribera, Patriarca de Antioquia, arzobispo y virrey de Valencia (1532-1611). Barcelona, 1960, pp. 43 y 62. 
siguió, incluso con un viaje en 1573 para supervisar dichas obras ${ }^{20}$. Además, con la herencia paterna, Juan de Ribera se permitió la construcción y decoración de una villa de recreo de corte manierista donde se combinaba jardín y Antiquarium conocida como la Casa del Huerto en el término de Alboraya, influida seguramente por el palacio sevillano de su padre reconstruido y ornado por Tortello.

En definitiva, esta estrecha relación familiar, educativa, cultural, de confianza si cabe, permite apuntar que Juan de Ribera compartiera con su padre unos gustos cultos y eruditos de corte humanista, ocultos por la lectura tridentina y devocional de su fundación y del posterior proceso de beatificación ${ }^{21}$.

De la misma manera que don Per Afán de Ribera durante su virreinato en la ciudad partenopea hizo acopio de una extraordinaria colección de esculturas antiguas que trasladó a su nuevo palacio sevillano dentro de un programa de integración de las piezas en un marco arquitectónico ex-novo; Juan de Ribera gastó dos mil ducados en una serie de escultuas antiguas y piezas arquitectónicas que le otorgaban un tono de prestigio y de erudición, como tan solo las antigüedades sabían darlo, pero que además le vinculaba nuevamente a la figura paterna recién fallecida ${ }^{22}$.

\section{LOS ELEMENTOS ARQUITECTÓNICOS TRAIIDOS DE NÁPOLES}

Aunque las piezas arquitectónicas no son el tema principal que nos ocupa, es necesario comentar algunos datos que aparecen en la documentación con el fin de perfilar o profundizar en nuestra teoría, y apuntar ideas que otros especialistas de este ámbito puedan desarrollar.

El interés de Juan de Ribera por la arquitectura resulta un tanto contradictorio. Por una parte en su rica biblioteca que contaba con libros relativos a las artes y las ciencias (matemáticas, astronomía, música, botánica, geografía, anatomía, zoología...) solo existía un ejemplar De Architectura... de Vitrubio, en su edición de Perugia de $1536^{23}$. Además, la supervisión de la construcción del Colegio la dejó en manos de Miguel de Espinosa que tuvo autoridad para modificar a partir de las trazas dadas $^{24}$. Esta aparente despreocupación por la arquitectura teórica contrasta con la continua adquisición de elementos arquitectónicos de diferentes materiales para dicha construcción, procedentes de diferentes zonas del ámbito nacional, pero

20. Romero Medina, Raúl: «Tened poco aderezo y muy honesto. El mecenazgo de Don Juan de Ribera en el arzobispado de Sevilla: la fundación del colegio-hospital de la sangre y del convento del Corpus Christi en Bornos (1571-1597)», El Patriarca Ribera y su tiempo. Religión, cultura y política en la Edad Moderna. Valencia, Palacio de Colomina, 2011, CALLAdo Estela, Emilio (ed.) Valencia, Institució Alfons el Magnànim/Diputació de Valencia, 2012, pp. $569-589$.

21. Lleó CAÑAL, Vicente: «El medio artístico y cultural en el que se formó San Juan de Ribera», Actas de las Jornadas Una religiosa urbanidad. San Juan de Ribera y el Colegio del Patriarca en la Cultura artística de su Tiempo. Valencia, 2013, pp. 73-80.

22. «Sus señorías han vendido al Patriarca mi señor todas las piedras, mármoles que están en la ciudad de Cartagena ... por precio de dos mil ducados». ACCV, fondo interno, LE 3.1.

23. Benito Doménech, Fernando: Pintura y pintores... p.27.

24. Miguel de Espinosa fue la persona de confianza de Juan de Ribera desde Badajoz donde había actuado de limosnero del prelado. En Valencia le nombró obispo de Marruecos y auxiliar suyo en la sede valentina, y fue el primer rector del Colegio según la carta fundacional del mismo. 
también italianas, que marcarían el estilo del Colegio. El ejemplo más significativo es el lote de columnas adquiridas a doña Ana de Portugal y de Borja, viuda del duque de Pastrana, en un largo proceso que abarca desde 1596 a I599, con testigos y peritos para reconocer y dictaminar el estado de las columnas con las que se construyó el claustro ${ }^{25}$.

No solo se adquiría material arquitectónico para reutilizar y construir su fundación sino que también en la extensa contabilidad del Colegio se consignan los canteros y picapedreros que cobran por modificar y adaptar dichos materiales, tal y como aparece en la documentación de la fábrica del Colegio: «desmenuir y adelgaçar dos columnas de mármol para el retablo de nuestra señora», «adelgaçar y estriar dos colunas grandes de pedra mármol» para el retablo del Ángel Custodio donde se veneraban las reliquias, o «deshazer las puertas de mármol y jaspes que estavan a los lados del altar mayor, y bolverlas a modo de capillas pequeñas, quitando y anyadiendo todo lo que fuere necesario para poder poner un quadro en cada una dellas» ${ }^{26}$

Este historial de adquisiciones con el fin de reutilizar materiales especialmente ricos tiene un cariz similar al de su padre del cual sabemos, por el primer inventario de la casa de los Alcalá de I588, que la mayor parte de las obras guardadas procedentes de Nápoles, eran de carácter arquitectónico compuestas por basas, capiteles, columnas, piezas para una portada y mobiliario de mármol ${ }^{27}$.

Según la nueva documentación, Juan de Ribera también adquirió un gran y variado conjunto de elementos arquitectónicos que posiblemente se utilizaron en la construcción de su Colegio o se incorporaron a sus villas de recreo ${ }^{28}$. Se mencionan siete columnas de mármol napolitano (sin basas ni capiteles en seis de ellas) y dos columnas de yeso. Además, de forma poco clara, el documento cita una portada de jaspe, mientras que en el albarán la desglosa en dos cajas (473 y 474, respectivamente) de la siguiente manera «un armiche de mármol de mesqueo para una portada» $\mathrm{y}$ «un arquitrabe y un friso de la portada del mismo mármol», a lo que se añade un comentario sobre su estado de conservación «en la portada faltan seis piezas y las que hay están quebradas y maltratadas». Esta portada se podría referir a la de acceso a la sacristía de la iglesia del colegio de autor desconocido. Pocos datos documentales se tienen de esta puerta, puesto que la más conocida es la de la capilla de San Mauro realizada también en mármol y jaspe pero firmada por el cantero Gaspar Bruel, y que según la contratación de 1599 «se obliga de hacer (...) una puerta la qual está a mano izquierda del altar mayor del dicho collegio y seminario conforme

25. Pero existen otras referencias sobre este asunto, como las seis columnas de jaspe verde para el retablo mayor; las otras seis columnas de mármol de ocho palmos de altura que Juan de Ribera compró en julio de 1600 , a un tal Luis Espieño, natural de Marsella; o la relación con Damián Pla, natural de Olula, en el reino de Granada que le suministró tras varios viajes dos columnas de 15 palmos, dos basas y un capitel de mármol, entre otros piezas arquitectónicas. Benito Doménech, Fernando: La arquitectura del Colegio del Patriarca y sus artífices. Valencia, Federico Doménech, 1981, p. 127.

26. Este tipo de arreglos fueron hechos por Bartolomé Abril, cantero natural de Génova que trabaja para el Patriarca sólo y en colaboración con Juan Bautista Semería. Idem, p. 102.

27. Méndez Rodríguez, Luis: op. cit. p. 239.

28. ACCV, fondo interno, LE.3.1. En el inventario o memorial de mármoles y piedras hay 16 cajas exclusivamente con piezas arquitectónicas y otras dos que comparten con esculturas. 


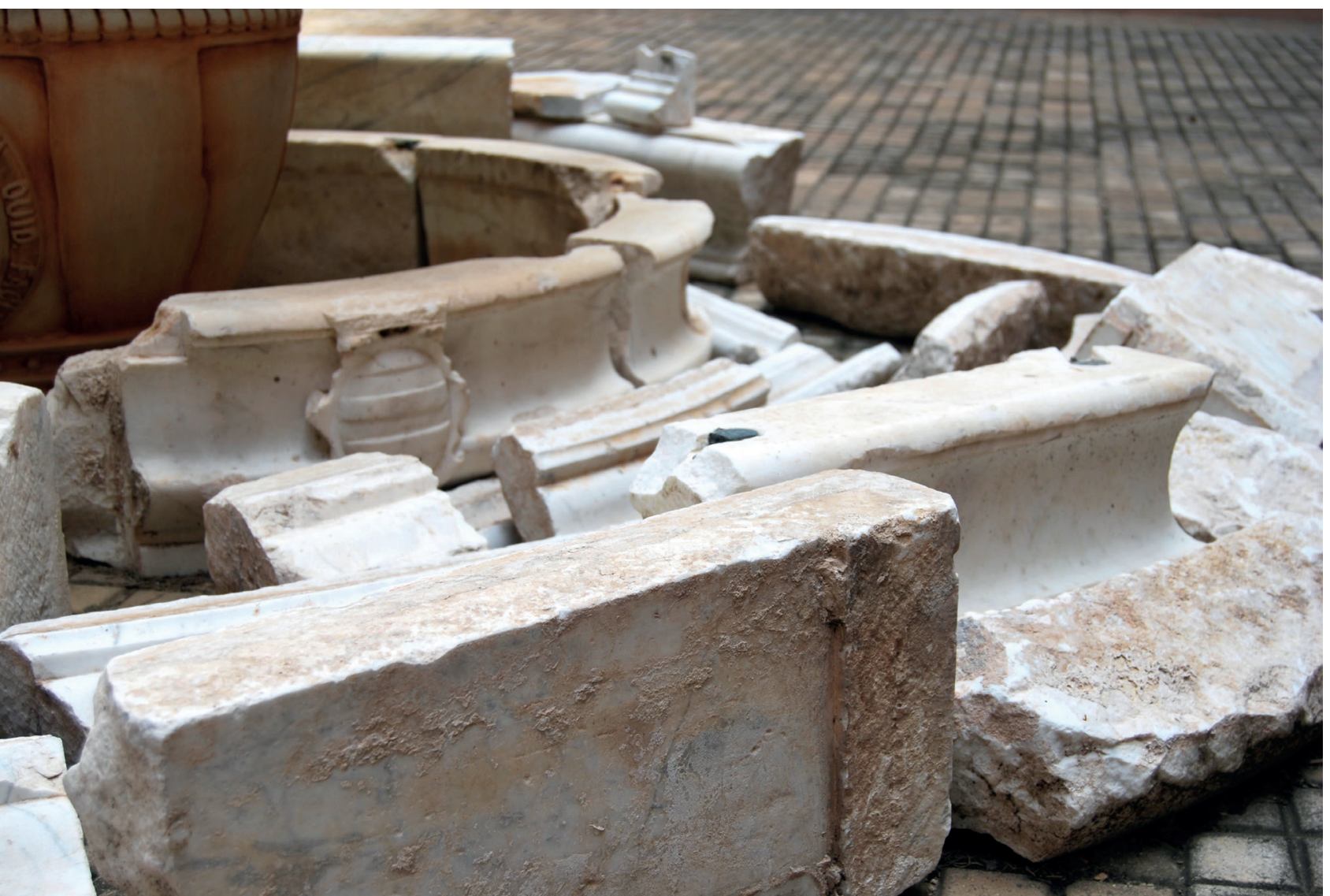

FIGURA 2. FUENTE DE MÁRMOL PROCEDENTE DE NÁPOLES

a una otra que está en el mismo collegio, ni más grande ni más chica y conforme a las cornisas y arquitrave y la misma ordinança que tiene la que está asentada ${ }^{29}$. Seguramente, para la puerta de la sacristía se aprovechase el material originario de Nápoles y la portada de la capilla de San Mauro se imitara en todo, incluso en los materiales, a la primera.

Especial relevancia tienen también las dos fuentes, la primera la del monasterio agustino de San Leandro de Cartagena, de jaspe, con escasos datos descriptivos y de la que no sabemos nada, ni siquiera si llegó a trasladarse a Valencia, puesto que no se tiene constancia de su existencia en el Colegio, si bien se pudo instalar en alguna de sus villas ${ }^{30}$. La segunda fuente es quizás la más interesante, puesto que se conserva en el Colegio y se relaciona en la documentación (FIGURA 2). Según el

29. Benito Doménech, Fernando: La arquitectura del Colegio del Patriarca... p. 58.

30. Como dato, casi anecdótico, según estos documentos, el padre prior del convento no quería hacer entrega, en negociaciones previas, esa pieza tan excepcional y en funcionamiento, para lo que don Miguel Crespo portaba también una paulina del nuncio, que es una carta o despacho de excomunión que se expide en los tribunales pontificios para el descubrimiento de algo que se sospecha haber sido robado u oculta maliciosamente. Coloquialmente, reprensión áspera y fuerte. http://www.rae.es/rae.html 


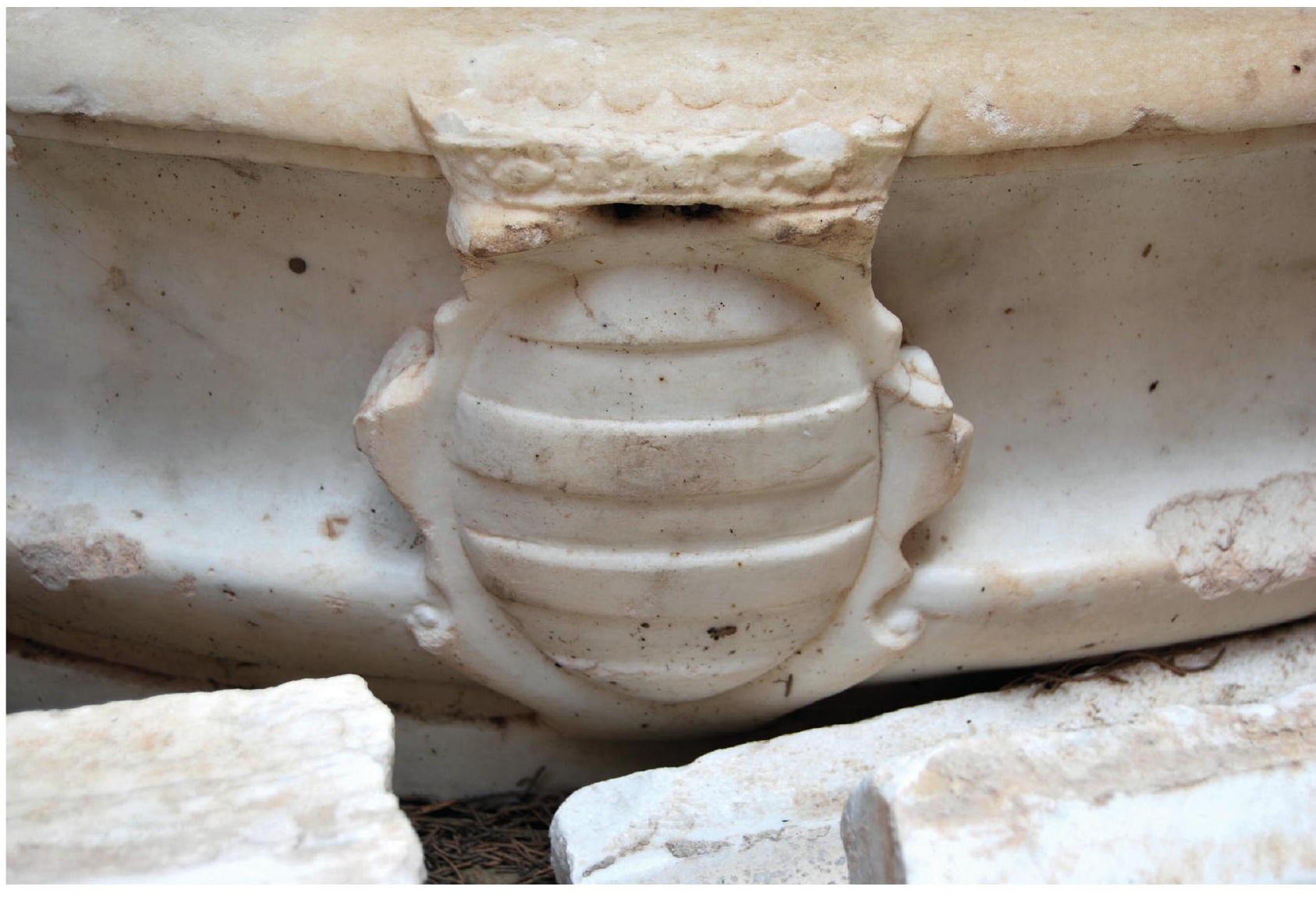

FIGURA 3. FUENTE DE MÁRMOL CON EL ESCUDO DE LOS RIBERA Y DUQUES DE ALCALÁ

documento aparece despiezada, en bastante mal estado y guardada en varias cajas: «En la fuente faltan algunas piezas que no podemos decir por no estar armada pero ella viene hecha pedazos y muy maltratadas por haberse deshecho del lugar donde estaba puesta y por estar como estaba en un lugar muy común y entre otras cosas faltan los mascarones $»^{31}$. Aparte de esta somera descripción, en otro punto se especifica que algunas piezas llevan «las armas de su Excelencia» sin duda refiriéndose a las del i duque de Alcalá que es el elemento que nos ha permitido identificarla. Actualmente, las piezas se encuentran repartidas en el Colegio en un buen estado de conservación y donde se destaca el blasón familiar de los Ribera hasta cuatro veces (en campo de oro con tres fajas de sinople y timbrado con la corona real española) (FIGURA 3).

Esta fuente se ha de relacionar con la que en 1603 los canteros Bartolomé Abril y Juan Bautista Semeria modificaron, trabajando las piezas originales de mármol napolitano para el vaso inferior, mientras que la piedra de Ribarroja sería utilizada

31. ACCV, fondo interno, LE 3.1. Según el listado de cajas, la fuente se encontraba despiezada en las siguientes cajas: $485,486,487,488,489,490,491$ y 492. 
como basamento ${ }^{32}$, que posteriormente fue reproducida en litografías y fotografías antiguas donde se la ve coronada con la estatua romana «la palletera», en el centro del claustro del colegio hasta I894-1896, fecha en la que se instaló la escultura sedente del Patriarca Ribera de Benlliure ${ }^{33}$. Tormo, más tarde, también la describe igualmente, pero ya en un patio secundario, «en un patio, la fuente labrada por Abril y Semeria, puesta trescientos años en el claustro, con la estatua romana de Ceres, la legendaria palletera ${ }^{34}$.

El interés de Juan de Ribera en esta fuente va más allá de señalar con un hito renacentista el centro del patio de su nueva fundación, puesto que al representarse en la fuente las armas del duque de Alcalá, su padre, se establece un vínculo histórico y de honor genealógico con su progenitor y su linaje.

Por último, mencionar una pieza de mobiliario de mármol, descrita en el documento como «una mesa cuadrada de mármol que llaman Mesquio, es toda de una pieza, fue de don Fernando de Torres» que bien se puede identificar con algunas de las descritas en uno de los aposentos del palacete del Huerto «una mesilla de jaspe de palmo y medio... y otra mesilla de alabastro de dos palmos y medio» ${ }^{35}$. Estos muebles se deben de considerar como habituales en la decoración de las casas porque en $\mathrm{I592}$, se compraron dos mesas de jaspe por veinte libras, que junto a la compra de diez bolas de ese mismo material ascendió a 136 reales $^{36}$.

Actualmente, no existe ninguna mesa ni de jaspe ni de alabastro, pero sí que restan cuatro grandes patas de material noble que probablemente pertenecieran a dichas mesas. Al margen de la existencia o no de este mueble, la importancia esta vez se dirige hacia el nombre de Fernando de Torres, puesto que este señor fue junto al anticuario Adrian Spadafora y en menor medida, al escultor Giuliano Menichini, el principal agente que tuvo Per Afán de Ribera para la gestión y compra de objetos antiguos en Roma y que luego enviaba a Nápoles. El valor, por tanto, estriba en que las esculturas y otras piezas artísticas de Juan de Ribera estaban siendo adquiridas, (y posiblemente también fuera asesorado) por el mismo personal que el del duque ${ }^{37}$.

\section{UNA COLECCIÓN DE ESCULTURA ANTIGUA EN LA VALENCIA DE FINALES DEL SIGLO XVI}

Del documento Memorias de los mármoles... se han extraído diferentes datos que recuperan un perfil de la figura de Juan de Ribera que enriquece el hasta ahora visto: su filiación al linaje de los Ribera y sobre todo la estrecha relación con su padre, el

32. Benito Doménech, Fernando: La arquitectura del Colegio del Patriarca... p. 49.

33. Llorente, Teodoro: Valencia. Sus monumentos y Artes. Su Naturaleza e Historia (2 vols.) Barcelona, 1887. Valencia, ed. fac. Valencia, 1980, p. 855.

34. Tormo, Elías: Guía de España. Levante. Madrid, 1923, p. 112.

35. ACCV, fondo interno, LE, 1.1, fol 44R.

36. Benito DoméneCH, Fernando: La arquitectura del Colegio del Patriarca... p. 104.

37. Fernando de Torres ofreció al rey Felipe II, en 1561, la posibilidad de adquirir las esculturas de Alessandro Corvino, que finalmente no le interesaron y que terminaron en manos de los cardenales Farnese y Maffei. MoráN TURINA, Miguel: La memoria de las Piedras... p. 212. 
I duque de Alcalá, el precio por el que adquirió parte de la colección de su padre, la constatación de la continúa adquisición de elementos arquitectónicos y mobiliario (en este caso italiano) y el contacto con los marchantes de su padre como es el caso de don Fernando de Torres. Sin embargo, especialmente interesante es el grupo de esculturas que menciona el documento que permiten esclarecer datos sobre el origen de algunas de ellas y relacionarlas con las existentes. Son cinco esculturas y dos cabezas las que se citan en el texto, de las cuales tres piezas no existen en la actualidad en el Colegio, mientras que las otras dos sí se pueden identificar con las existentes. De las obras desaparecidas resulta especialmente interesante la escultura de Paris por ser la mejor descrita, además de identificarla iconográficamente: «Una estatua de hombre sin barbas. Antigua y desnuda que tiene el lado derecho arrimado a un tronco de un árbol y al mismo lado está un perro sobre los pies mirando a un racimo de piñas que tiene la estatua en la mano derecha y con la izquierda assia un bastón que le sube por el brazo hasta el hombro. Es la figura de Paris que se halló en Puzol».

Esto mismo sucede con la figura alegórica de un río: «En una caja $n .{ }^{\circ} 470$ vino una estatua pequeña de hombre sin barbas con manto que está echada sobre el lado izquierdo y tiene debajo del brazo del un caño para hijar agua. Es figura de un río. Hallose en Puzol».

La tercera pieza es un perro de mármol sentado

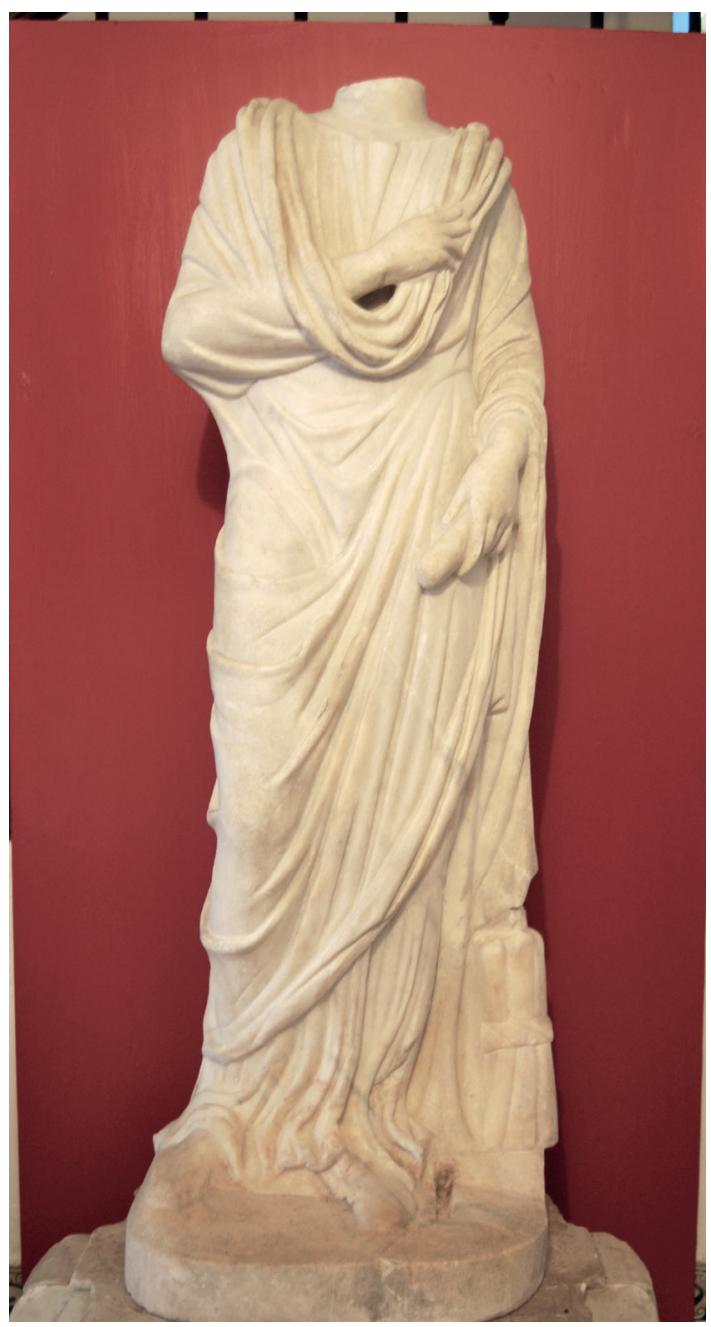

FIGURA 4. «LA PALLETERA»

Escultura romana de Pozzuoli. sobre una base que se podría parecer al Mastín de los Uffizi ${ }^{3}$. También se citan «dos cabezas de mármol pequeñas» sin más descripción ni datos de procedencia ni de época, ubicadas en la caja $n .^{\circ} 493$ junto a dos columnas de yeso, trozos de mármol y otros materiales.

Entre las piezas existentes en el Colegio e identificadas en la documentación está la escultura de cuerpo entero conocida como la Palletera (Figura 4), «En otra caja, n. ${ }^{\circ}$ 494, Una estatua de mujer de mármol blanco con manto y en la mano izquierda un bastoncillo. En el pedestal Inscripción Aurelia. Hallose en Puzol». Esta obra

38. El arte animalístico romano de gran tradición en la escultura clásica tuvo un revival en el siglo XVI, al unir el gusto por lo antiguo, como pieza original y el eminente carácter popular y amable que respiran estas piezas. El mejor ejemplo es la Sala de los Animales del Museo Pío-Clementino en el Vaticano, fruto de las excavaciones efectuadas bajo los pontificados de Clemente XIV y de Pío VI que más tarde fueron restauradas por artistas de los siglos XVII y XVIII como Antonio Franzoni. SPINOLA, Giandomenico, RICCI, Giovanni, MaINARDI, Danilo: «La Sala de los Animales en el Vaticano: el Zoológico de piedra», FMR: revista de arte y cultura de la imagen. 1 (2004), pp. 53-84. 
es la única que aparece recogida por los cronistas e historiadores que han tratado el Colegio de Corpus Christi. Orellana ya en el siglo xvill, en su Valencia Antigua y Moderna, la describe en el medio del patio,

\begin{abstract}
...que parece figura de mujer, y el vulgo suele llamarla la Congretera, esto es mujer que vende deditos, que vulgarmente llamamos brasets y antes decían congrets (panecillos de harina, azúcar y huevos de forma oblonga y consistencia blanda) ... pero en verdad, dicha estatua representa Siringa, símbolo muy oportuno en aquel Colegio, como casa de Verdadero Dios Pan, siendo Colegio de Corpus Christi, y lo que el vulgo le parecen dedillos ... es el silbato o abogue con los canutos, según le acostumbran los pastores de siete ordenes según Virgilio39.
\end{abstract}

Llorente, en el siglo siguiente, la describe así: «En el centro de aquel magnífico patio hay una fuente, y sobre ella una estatua antigua, de Ceres sin duda, mal restaurada. Dícese que se halló al abrir cimientos para la obra», y además aporta una leyenda fabulosa en nota a pie de página sobre su significado ${ }^{40}$. Esta lectura del todo fantástica, junto al desconocimiento del documento, permitió crear una nue-

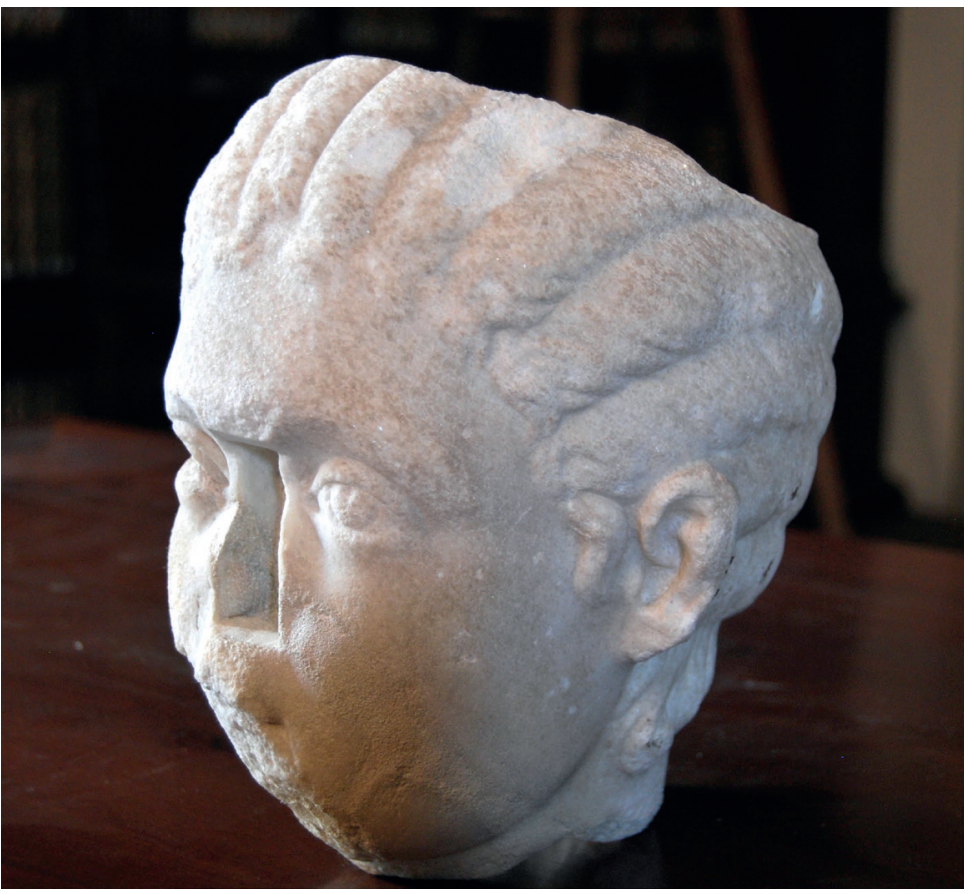

FIGURA 5. CABEZA DE LA ESCULTURA DE «LA PALLETERA» va leyenda, más factible por otra parte, al considerarla como pieza encontrada en la excavación del solar para construir los cimientos del templo. Además, Benito Doménech cita un documento de pago de I605 a Bartolomé Abril y Juan Bautista Semeria «por quitar la figura que estaba en la fuente del claustro del colegio y poner otra que hay echa y por hazerle el ropaje en las spaldas» ${ }^{41}$, que nos habla por una parte, de una escultura anterior a la Palletera sin referencia alguna, y por otra de que la pieza que nos ocupa fue rehecha por estos escultores con el fin de incorporarla al claustro donde estuvo hasta finales del siglo XIX.

En realidad, se trata de una escultura togada, que a priori nos

39. Orellana, Marcos Antonio: Valencia. Antigua y Moderna. Valencia. Ed. fac. 1985. T. I, p. 431.

40. Llorente, Teodoro: op. cit. T.I, p. 856, «Llama el vulgo a esta estatua la palletera (vendedora de pajuelas), porque parece de pajuelas el haz de espigas que tiene a sus pies; y ha inventado una leyenda para explicar su presencia en aquel sitio. Dice que una de las casitas que habían de derribarse para la obra del colegio, era la de una pobre Palletera, y que ésta se opuso tenazmente a su venta. Por más dinero que le ofrecieron, no quiso ceder, hasta que exigió y obtuvo que se le erigiese una estatua en el punto que ocupaba su destruido hogar».

41. Benito Doménech, Fernando: Pinturas y pintores... p. 102. 
remite a la representación de un magistrado, si bien se leía sobre un pequeño plinto la inscripción AURELIA, según la documentación antigua, texto que ha desaparecido en la actualidad y que ayuda a entender por qué nuestros historiadores la identificaron con Siringa y con Ceres. La estatua está labrada en un único bloque prismático de mármol blanco y parece ser obra de un artesano local que repite los modelos urbanos con fidelidad. Originariamente, la ejecución plana y sumaria del dorso evidencia que la visión de la estatua era frontal y por tanto debía de estar ubicada en un nicho abierto en la pared. De tamaño mayor al natural, la estatua debió evocar a un personaje de altísima dignidad vestida por una amplia toga y que porta los calcei patricii, calzado típico de individuos de elevada condición socio-política. El brazo derecho aparece plegado formando una tensión en las telas, característica del final de la época imperial, mientras que con la mano sujeta la toga en un gesto usual. El brazo izquierdo cae pegado al cuerpo y en su mano porta un báculo o bastoncillo ${ }^{42}$. La estatua tendría su cabeza original puesto que en el documento no especifica el faltante, un dato que se hubiera consignado como sucede en las descripciones de las otras piezas. Aunque, también

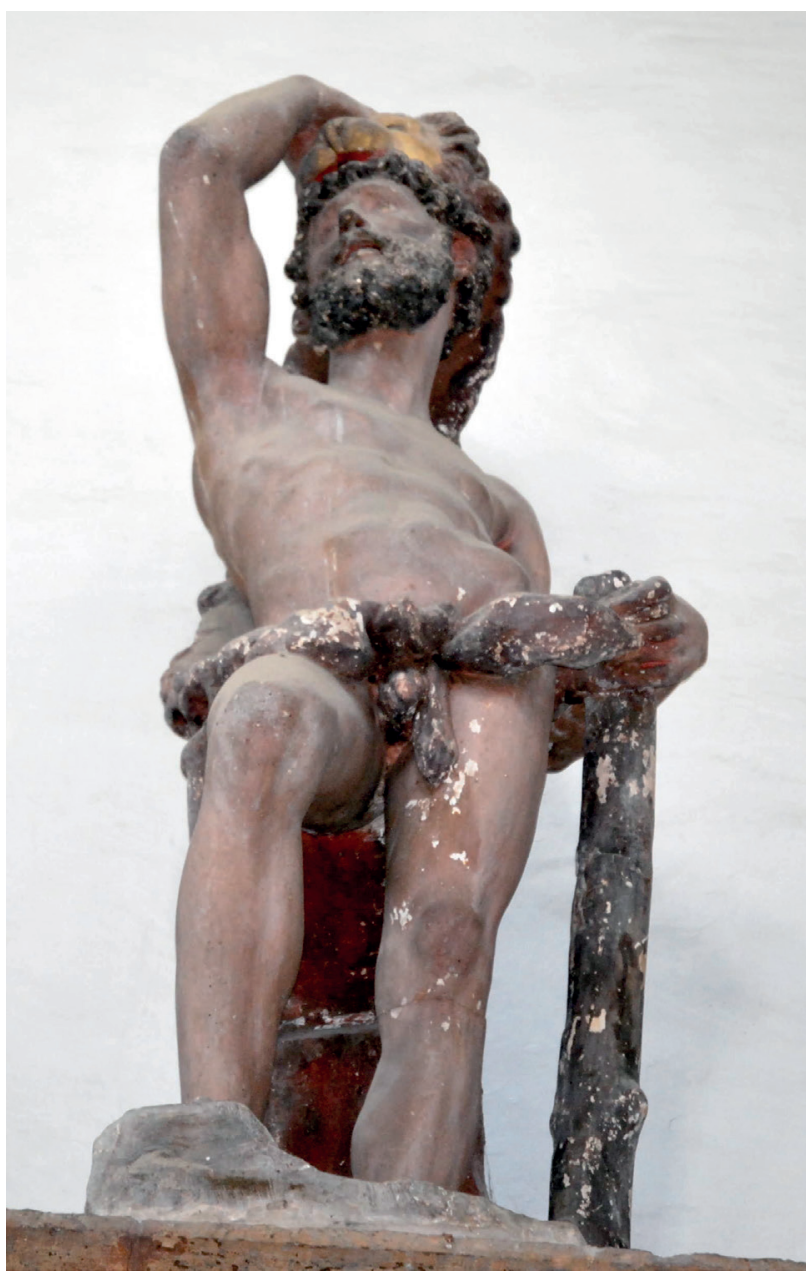

FIGURA 6. HÉRCULES, ESCULTURA ROMANA DE POZZUOLI. Cornisa de la portada de ingreso a la biblioteca del Real Colegio. podría ir sin cabeza y que ésta estuviera en otra caja y fuera la que se menciona en la número 493, y que una vez en Valencia, la cabeza se montara sobre el resto de la escultura y así apareciera en las ilustraciones y fotografías antiguas (FIGURA 5).

Esta cabeza muy deteriorada y restaurada junto a la Palletera por el IVC+R en el año 20I2, tiene erosionada determinadas zonas, con pérdidas de elementos como el ojo derecho o la propia nariz de la que queda solo la caja donde se incrustaría, además de un orificio de unos tres centímetros de diámetro que la atraviesa longitudinalmente. El cabello está estructurado a la manera griega, formando mechones de pelo en forma helicoidal y recogido todo en un moño sobre la nuca.

La otra pieza identificada (FIGURA 6) es la figura de Hércules que en la actualidad remata el entablamento de la puerta de la biblioteca del Colegio y que ha permitido

42. La tipología de la escultura, salvo por la ausencia de cabeza, recuerda la figura en mármol del joven de Herculano del museo napolitano datado en el siglo I d. de C. 
una lectura iconográfica de hondo simbolismo relacionada con el proyecto y la construcción de la escalera de acceso, donde los peldaños de la escalera más altos que los normales provocan un esfuerzo físico vinculado a la figura de Hércules y sus trabajos, de la misma manera que el acceso a los conocimientos, que encierra la biblioteca, supone un esfuerzo intelectual. Sin embargo, como propone Benito Doménech, la diferencia de altura de estos peldaños se debe a que la escalera sólo iba a tener dos alturas, pero más tarde, se pensó en construir una biblioteca en un piso superior lo cual obligó a continuar la obra de una manera imprecisa, pues la altura resultó ser de dieciséis escalones y no de veinte como aparecía en el contrato ${ }^{43}$.

El Hércules aparece descrito en el documento como «Una media estatua de mármol. Antigua desde el ombligo arriva con la cabeza gastada. Tiene los medios brazos, la cubierta con una piel de león. Es figura de Hércules. Hallose en Puzol». La descripción difiere en algunos elementos con la pieza existente, lo cual nos planteó la posibilidad de la existencia de otro Hércules en las colecciones de Juan de Ribera, sin embargo tras la consulta del inventario se eliminó esta posibilidad, puesto que aparece descrita de la siguiente manera «En el descanso que está al abajar de la escalera que sube a la dicha librería de dicho palacio Archipiscopal se halló una estatua de masoneria de la figura de Ercules hecha en barro encarnado y separada con su adestral de lo mismo de cuatro palmos de alto». Una ubicación que sin duda influyó posiblemente en la colocación posterior en lo alto de la cornisa de la portada de ingreso a la biblioteca del Colegio.

El hecho de que en el documento lo describa como «Una media estatua de mármol. Antigua desde el ombligo...» nos hace pensar que la escultura fuese restaurada a su llegada a Valencia, tal y como había pasado con la escultura togada, reconstruyendo las partes perdidas y pintando las carnaciones para disimular los añadidos a la vez que darle una mayor prestancia, hasta tal punto que en la descripción que se hace en el inventario se describe como de masoneria. De todos modos y pese a la altura, donde está ubicada que impide un estudio pormenorizado, la pieza responde claramente a una estética clasicista con un acusado contraposto, con un soberbio estudio anatómico de proporciones clásicas, e incluso con una temática inusual en el ámbito de la escultura valenciana que nos remite, como el documento dice, a una pieza originaria del yacimiento napolitano.

Tanto en el caso de la Palletera como en el Hércules, la documentación de Memorias de los mármoles... nos ofrece un dato especialmente relevante como es el origen del yacimiento de Puzol, refiriéndose a Pozzuoli, de donde proceden las esculturas. Esta población de la Campania muy próxima a Nápoles fue en época romana un puerto especialmente activo por su comercio con el Oriente y por su ubicación al norte del golfo de Nápoles y ser el acceso para Isquia y Procida lo cual permitió el crecimiento de una gran ciudad con edificios y villas, monumentos y esculturas de las que se nutrieron las excavaciones iniciadas en el siglo xvı con el fin de obtener antigüedades y objetos variados al gusto de la época ${ }^{44}$.

43. Benito Doménech, Fernando: La arquitectura del Colegio del Patriarca... p. 76.

44. VenditTI, Mauro: «Una presenza vicereale a Pozzuoli: la dimora fortificata di don Pedro de Toledo», Napoli nobilissima, 5, Ser, 8, (2007), pp. 119-140. 
La otra pieza de esta dispersa colección es un Sátiro o Fauno, de bronce, situado en la escalera interior del claustro, en lo alto de la puerta que da acceso al primer piso (FIGURA 7). Esta pequeña escultura, no aparece citada en Memorias de los mármoles... aunque seguramente también proceda de Pozzuoli o de otros yacimientos de donde se nutría la colección del duque de Alcalá. Sin embargo, sí que aparece descrita con detenimiento en el inventario post-mortem del Patriarca en una de las estancias del palacio del Huerto de la siguiente manera: «Un sátiro que llaman dios de las aguas, de bronce, de tres palmos de alto con un cesto lleno de flores al hombro y una ydria en la mano derecha con el pie de madera de blanco y oro» ${ }^{45}$.

Existen otras dos piezas similares en dicho inventario que nos habla del gusto, para nada casual, de Juan de Ribera por estas esculturas profanas y clasicistas: una en otra habitación del mismo palacete «otro sátiro de medio largo con los pies de montes, de bronce sentado sobre una peana de lo mismo y derramando una ydria de agua» ${ }^{46}$, que parece recordar a la pequeña escultura que personificaba a un río antes mencionada; y la otra en un aposento del palacio arzobispal rodeado de libros, cuadros, floreros de bronce y bufetes de maderas nobles «sátiro de bronce pequeño en forma de hombre mirándose la mano» ${ }^{47}$.

\section{LOS BUSTOS DE LA ANTIGÜEDAD Y OTROS ELEMENTOS DECORATIVOS EN LA BIBLIOTECA DE JUAN DE RIBERA}

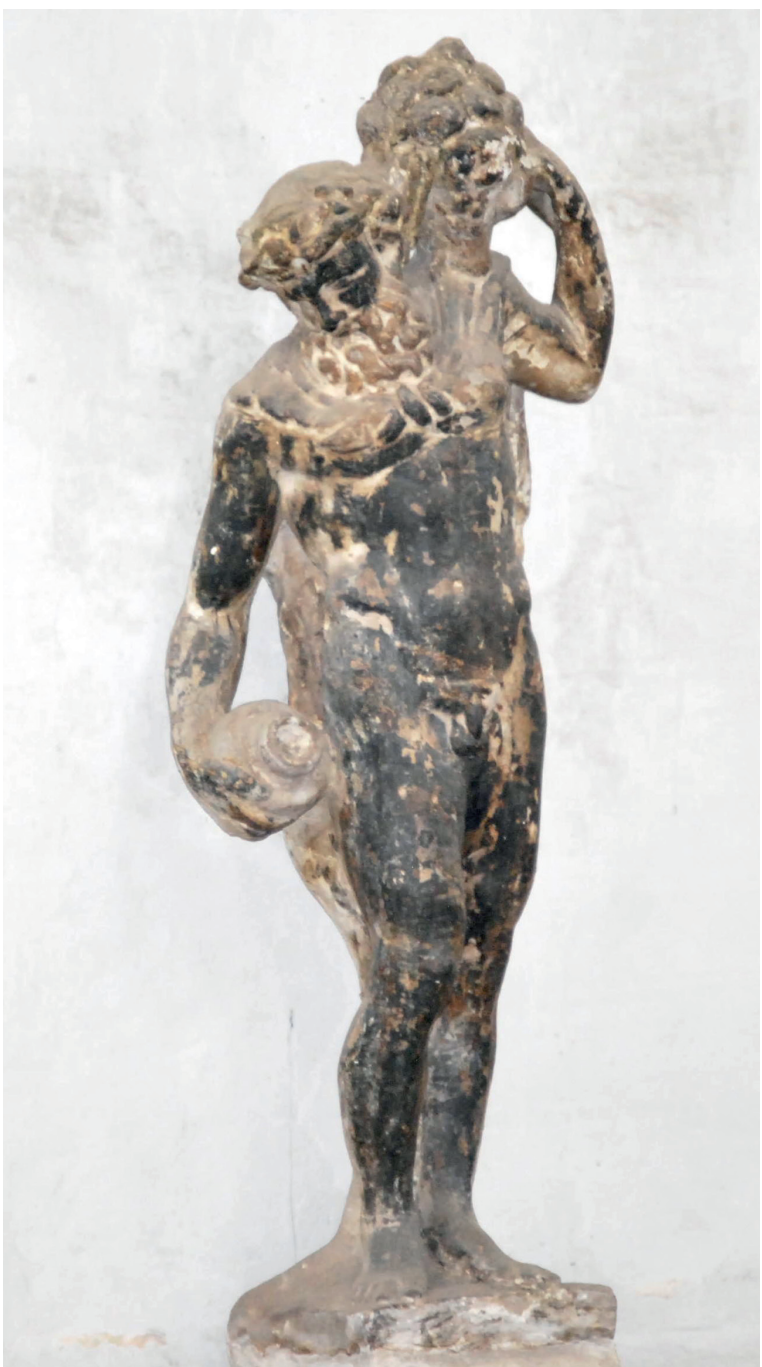

FIGURA 7. SÁTIRO DE BRONCE

Cornisa de la portada de ingreso al primer piso del claustro del Real Colegio.

En el inventario de i6i se mencionan los bustos de emperadores que tenía Juan de Ribera en los aposentos de sus residencias, símbolo de poder al que pocos coleccionistas hispánicos tenían acceso, como era el caso de su padre, Per Afán de Ribera o el mismo rey Felipe 11. En uno de los palacetes se describen «catorze cabezas

45. ACCV, fondo interno, LE 1.1, fol. 158V-159R.

46. ACCV, fondo interno, LE 1.1, fol. 159R.

47. ACCV, fondo interno, LE 1.1, fol. $56 \mathrm{~V}$. 
de emperadores romanos con los medios cuerpos de madera dorada y blanca de medio palmo de largo» ${ }^{48}$, que posiblemente se correspondan con la serie completa de los doce emperadores romanos junto a los bustos de Carlos v y de Felipe in que cierran el concepto de Nuevo Imperio, tal y como aparecen mencionados en tantas colecciones como la del príncipe Carlos ${ }^{49}$. Además, en el estudio conocido como de los tafetanes de la Casa del Huerto se cita sobre un estante «unas medias figuras de Emperadores de mármol con las cabezas de alabastro». En otros estantes, de la misma sala, se habla de hasta cinco «medias figuras de un emperador de mármol con la cabeza de alabastro» todas ellas alternadas con bolas de jaspe con sus pies de madera dorada y coloreada, pilas de jaspe gallonadas con los pies de cobre, columnas de alabastro y ramilletes de flores de bronce dorado, es decir, todo un ejemplo de magnificencia y poder acorde con la figura de Juan de Ribera ${ }^{50}$.

Desgraciadamente no se tienen noticias del origen de los bustos de emperadores. Los especialistas hablan de la gran demanda de escultura clásica tanto en Italia como fuera de ella, aunque a los coleccionistas del siglo xvı, no parecía importarles demasiado si se trataba de piezas clásicas auténticas, de restauraciones con muchas intervenciones o de trabajos recientes ${ }^{51}$. Tampoco se sabe nada sobre el recorrido histórico de estas piezas posterior a la muerte del Patriarca, ni siquiera aparecen mencionadas en las almonedas posteriores; lo que resulta evidente es que estas series de emperadores tenían un sentido claramente decorativo, correspondiente a un hombre culto y refinado, con una educación esmerada y cosmopolita, y con un gusto estético de corte italianizante, que tras su muerte no tenía cabida ni en el palacio arzobispal ni en el Colegio de Corpus Christi. En la actualidad, solo quedan unos cuantos bustos de corte clásico reconvertidos en mártires cristianos (posiblemente la razón de su pervivencia) localizados en la biblioteca del Patriarca.

Como se ha dicho, la construcción de la librería en el segundo piso del claustro es posterior a I602, año en el que se proyecta la escalera, y por tanto, la visión arquitectónica y estética que se tiene en la actualidad de la biblioteca del Patriarca Ribera no existía a la muerte del fundador, pero tampoco debe de diferenciarse demasiado de aquello que le hubiera gustado. Seguramente, sus continuadores tuvieron dos elementos para recrear una estética coherente que respetara la imagen de prestigio y solemnidad a la que se sumó, con el devenir del tiempo, el halo de santidad que se respira hoy en día en el colegio.

El primero aparece en el inicio de su testamento, donde deja una serie de órdenes sobre el destino de sus posesiones, y nos da una pista de cómo quería que se utilizaran en su fundación: «Queremos que todo lo que hubiere en mi guarda ropa y las cosillas que hubiese en mis capillas y estudios así de Ymagenes como de cuales quiera bufetes, mesas, alfombras, cestillos de plata o de jaspe, todo sirva para

48. ACCV, fondo interno, LE 1.1, fol. 172R-172V. Quizás Ilame la atención el hecho de que el cuerpo fuese descrito como de madera dorada, posiblemente una manera económica de conseguir este tipo de piezas, ya que tradicionalmente, en la documentación antigua sí que se diferencia entre bustos y cabezas de emperadores.

49. COPPEL, Rosario: op. cit. pp. 63-66.

50. ACCV, fondo interno, LE 1.1, fol. $243 \mathrm{R}, 243 \mathrm{~V}, 244 \mathrm{R}$ y $244 \mathrm{~V}$.

51. Coppel, Rosario: op. cit. p. 65. En este ámbito destaca el taller de Della Porta, uno de los más prolíficos de Roma, cuyos autores trabajaron sin una clara distinción entre original y copia. 


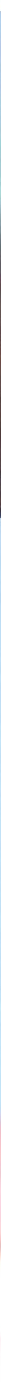

FIGURA 8. VISTA DE LAS BOLAS DE MÁRMOL CON UNA COLUMNA DECORADA CON GUIRNALDAS Y HOJAS DE PARRA Biblioteca del Real Colegio.

aderezo público del dicho colegio, poniéndose o en la sacristía o en las dos capillas altas que se han de hacer para los que estuvieran enfermos o para la librería». El segundo, son las descripciones pormenorizadas de las habitaciones con el mobiliario y demás decoración que aparece en el inventario de I6II. (FIGURA 8)

En la actualidad, la planta rectangular de la biblioteca está presidida por un testero a modo de altar rehundido en el muro y enmarcado por una portada de yeso de columnas corintias y un ático con el escudo de la casa. Los armarios de madera para libros son de un orden arquitectónico jónico con pilastras, arquitrabe, friso y cornisa y encima de ellos se ubican los restos de la colección de escultura antigua: bolas de jaspe con sus pies de madera dorada, pilas gallonadas de pórfido, columnas y obeliscos de mármol policromado, bustos de bronce dorados, de mármol y de piedra policromada. Por último, a modo de friso corrido discurren pinturas 


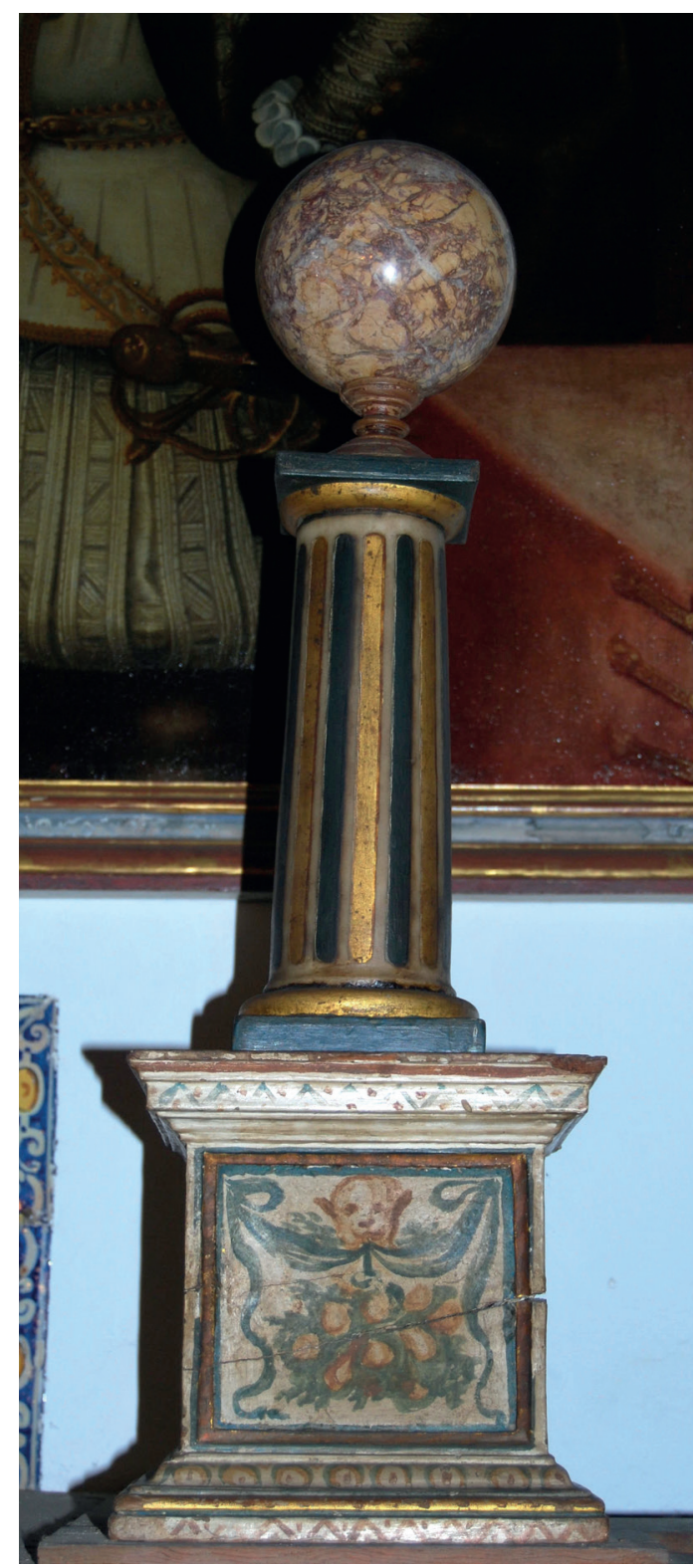

FIGURA 9. COLUMNA DECORADA CON GUIRNALDAS Y HOJAS DE PARRA

Biblioteca del Real Colegio. manieristas italianas y retratos de monarcas hispanos todas ellas relevantes tanto por su iconografía como por su calidad artística.

Los objetos menores como bolas, obeliscos y pilas se alternan sin orden de tamaño ni colorido con los bustos, y estos no son más que un resto de la cantidad de piezas similares que aparecen citadas en el inventario de I6II en las tres residencias decorando los diferentes aposentos. Lamentablemente no hemos encontrado ningún documento nuevo que mencione el origen italiano de estas piezas ya sea por adquisición o como regalo de su padre desde Nápoles. Por otra parte, sabemos que tras el fallecimiento del Patriarca y pese a la prohibición expresa del mismo, se produjo una serie de almonedas públicas donde se produjo una dispersión de este tipo de piezas menores ${ }^{52}$. (FIGURA 9)

En la actualidad restan ocho columnas y obeliscos de mármol blanco policromadas con bandas doradas con hojas de parra en el fuste. La estructura de estas piezas está formada por una basa o plinto, también policromada con guirnaldas a la romana, un fuste y una bola de jaspe como remate. Este coronamiento no es un añadido moderno posterior sino que así aparece descrito en el inventario de i6II, concretamente en la librería del palacio arzobispal: «dos pirámides de jaspe con sus bolas y remates de lo mismo (mármol) de cuatro palmos de alto» 53 . (FIGURA IO)

También existen 33 bolas de piedra de jaspe rosáceo sobre pequeñas basas de broce dorado con una pequeña lámina de oro, mientras que las bolas grandes reposan sobre un pedestal de madera dorada. Es así como aparecen descritas encima de las bufetes de madera de uno de los aposentos de la Casa del Huerto «Ocho bolas de jaspe grandes con los pies de madera de oro y colores» ${ }^{54}$

Por último, se cuentan I2 vasos o pilas del mismo jaspe que las bolas en dos formatos, unos más sencillos a modo de platos hondos y otros más elaborados, en forma gallonada. (FIGURA II)

52. Así en la tercera almoneda en la plaza de la seo del 18 de julio de 1615 se venden a Mossén Martínez y mosén Senent media docena de bolas de jaspe a cada uno por 16 sous, mientras que en la quinta almoneda en el mismo lugar el 8 de agosto del mismo año se venden a Joan Margarit dos bolas de jaspe por 5 sous y a Çapater 4 bolas de jaspe por 10 sous. BENITO DOMÉNECH, Fernando: La arquitectura del Colegio del Patriarca... pp. 209-211.

53. ACCV, fondo interno, LE 1.1, fol. 69 R.

54. ACCV, fondo interno, LE 1.1, fol. $242 R$. 


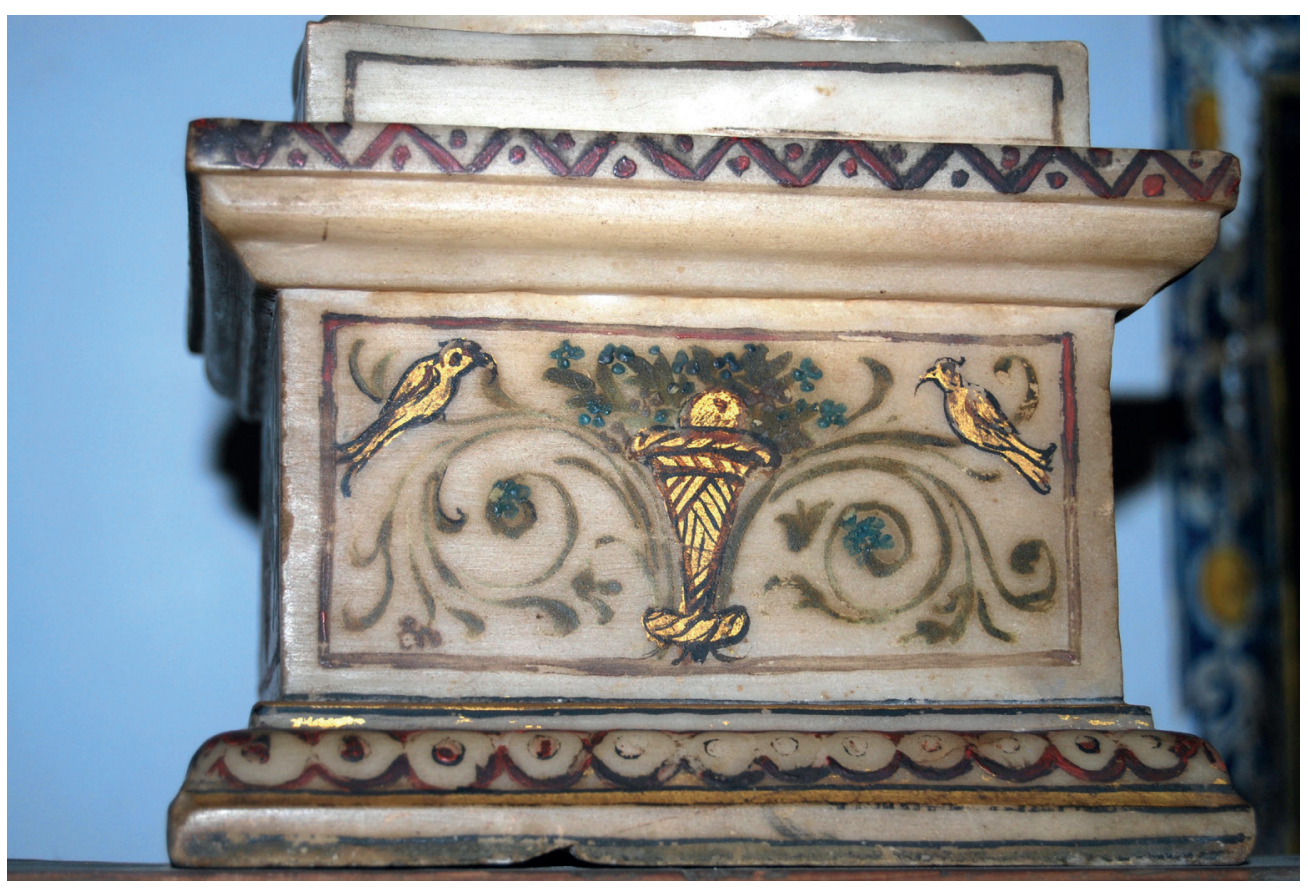

FIGURA 10. DETALLE DE LA DECORACIÓN DEL PLINTO DE LA COLUMNA

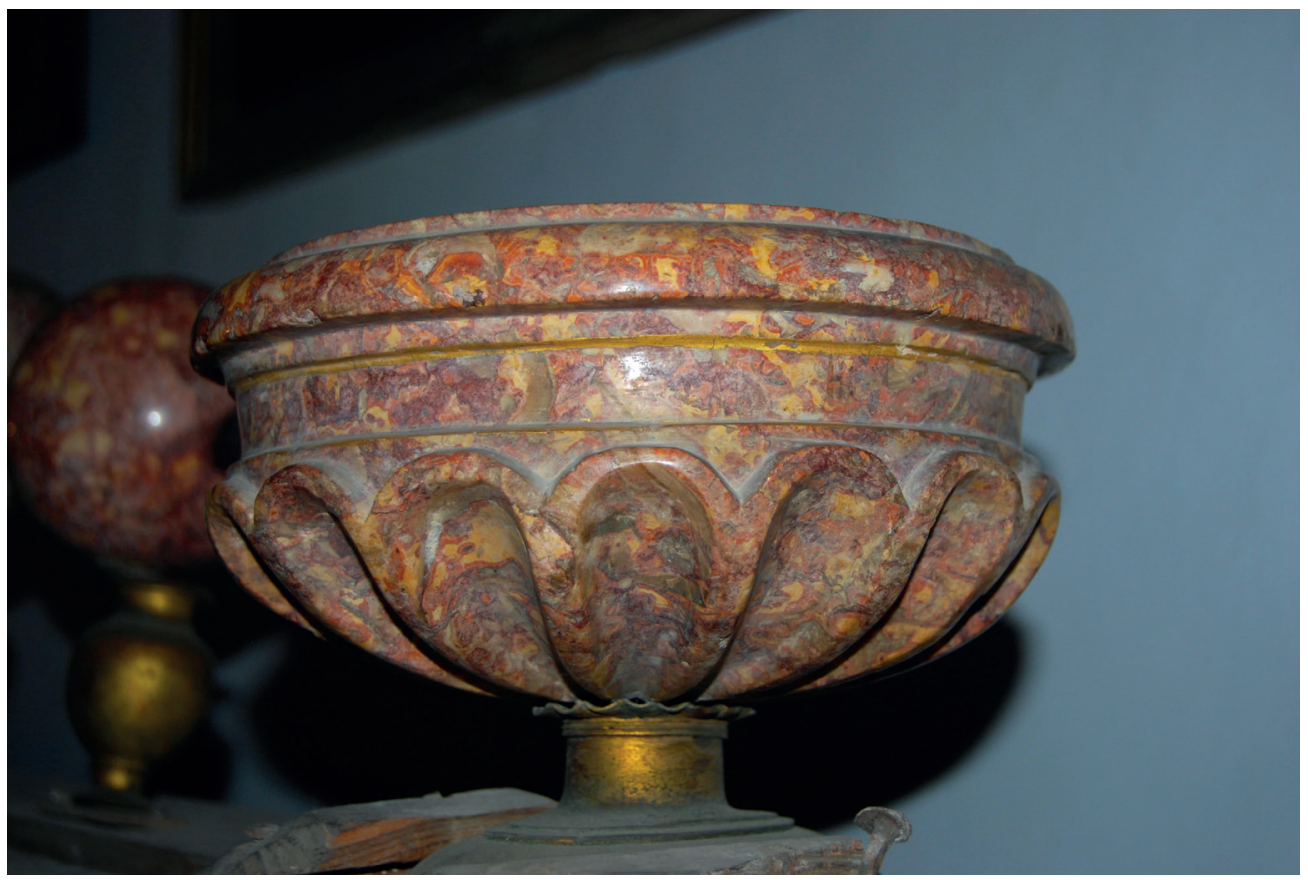

FIGURA 11. CUENCO GALLONADO 


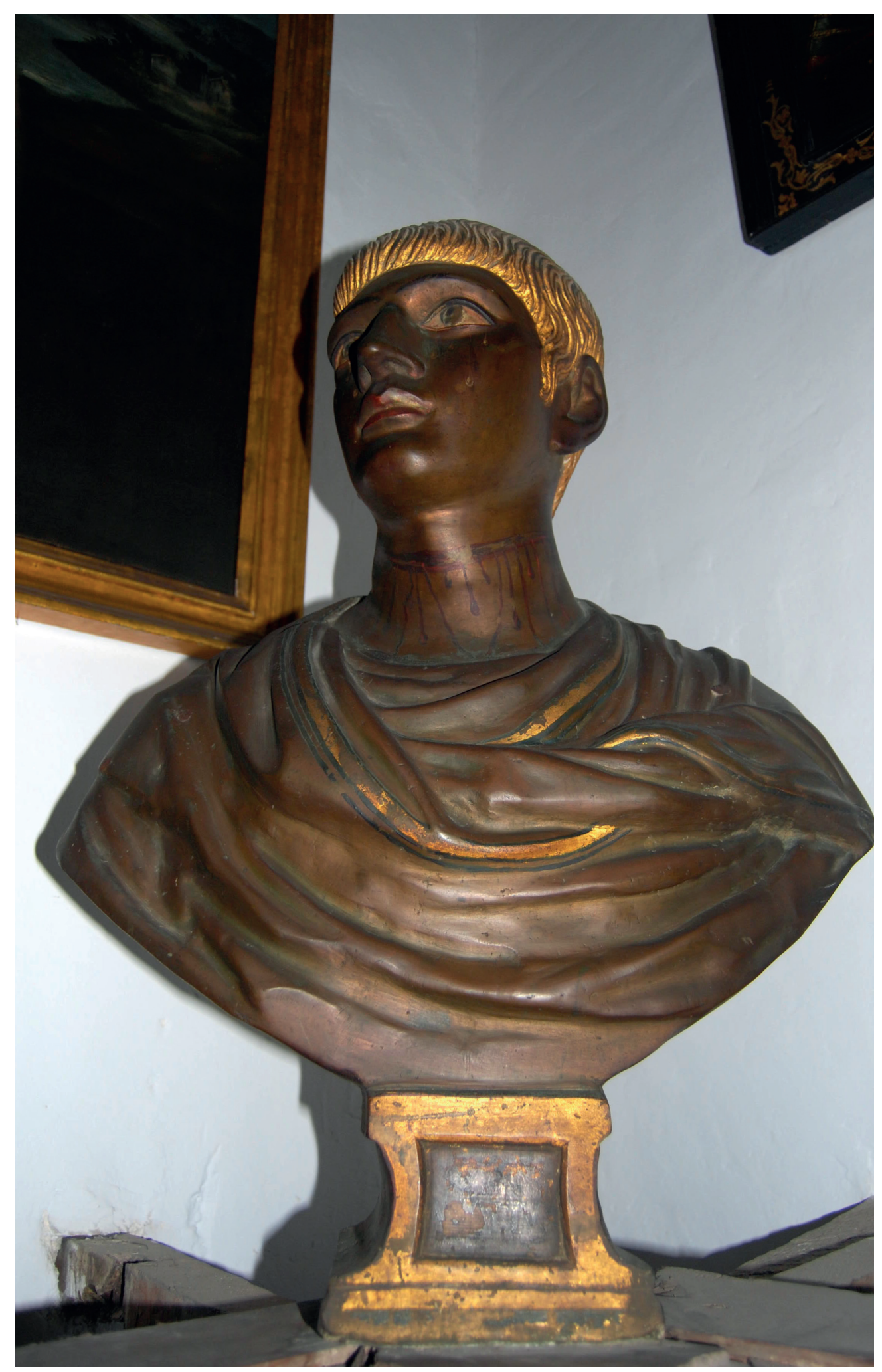

FIGURA 12. BUSTO ROMANO DE BRONCE CONVERTIDO EN MÁRTIR CRISTIANO 
En el inventario, en sendos aposentos de la Casa del Huerto, aparecen descritos con pies de bronce dorados y cuya función era la de tener flores frescas o ramilletes de bronce ${ }^{55}$.

Los ocho bustos antiguos reconvertidos en santos y mártires, son sin duda las piezas más interesantes del conjunto. No aparecen citados en Memorias de los mármoles... y tampoco se ha encontrado todavía documentación relativa a su adquisición que clarifique el origen de las mismas, sin embargo sí que aparecen identificadas en el inventario de i6II.

Actualmente situados en las esquinas de la biblioteca se ubican cuatro bustos de bronce pulimentados con aplicaciones de oro y pintados al óleo los ojos, la boca, las cejas y la cartela del pedestal. Dos de ellos son dos bustos masculinos y los otros dos femeninos. Los dos bustos femeninos son citados en el aposento segundo subiendo a mano derecha en la casa de Burjassot, de la siguiente manera y se pueden identificar claramente con las inscripciones que aparecen en su pedestales «Item Dos figuras de bronce con las cabezas doradas solas medias figuras con los nombres de Santa Justa y Rufina en forma de mártires con las peanas de madera pintadas de colores» ${ }^{56}$. En el frente opuesto, flanqueando la entrada están los dos bustos masculinos, que reproducen a San Iulia y otro, cuya inscripción está oscurecida o borrada y que hemos querido identificar con un San Acasio que aparece descrito en una de las salas del palacio arzobispal «Item. Una media figura de bronce con la cabeza dorada del retrato de San Acasio con la basis de madera pintada de colores» ${ }^{57}$, si bien en el inventario de I6II, se menciona otro busto de bronce dorado que nos remite a la existencia de más piezas de este tipo en sus diferentes casas ${ }^{58}$. (FIGURA I2)

Además, quedan tres bustos de mármol, parcialmente identificados. En el lateral derecho, los de San Mauro y San Marino. El primero, descrito en la casa de Burjassot «Item. Una media figura de mármol con la cabeza dorada de tres palmos de alto con el nombre de San Mauro mártir y el asiento cuadrado de madera pintado de colores ${ }^{59}$. En el caso de San Marino, es inventariado en el palacio de Alboraya y descrito de la siguiente manera «Item. Una media figura de alabastro con la cabeza y dobleces de la ropa dorados con el nombre de san Marino del mismo alabastro y pintado de colores ${ }^{60}$. Esta misma pieza se incorporó al inventario del doctor Joan Gil Trulench, junto a ropa, muebles, lienzos y demás objetos suntuarios para ser vendidas, hecho que no sucedió, al no citarse en ninguna de las almonedas públicas que se hicieron ${ }^{61}$. (FIGURA I3)

55. ACCV, fondo interno, LE 1.1, fol. 149R y $158 \mathrm{~V}$.

56. ACCV, fondo interno, LE 1.1, fol. 174V.

57. ACCV, fondo interno, LE 1.1, fol. 141V.

58. «Item. Una media figura de bronce con la cabeza dorada y en su prefronte el nombre con la basis de madera pintada». ACCV, fondo interno, LE 1.1, fol. 153R.

59. ACCV, fondo interno, LE 1.1, fol. 196V. La importancia de san Mauro en este Real Colegio se debe a que se custodia el cuerpo del joven mártir solicitado por el Patriarca a Roma en 1599. BENITO DomÉnECH, Fernando: «A propósito de un cuadro de Baglione falsamente atribuido a Ribalta», Traza y Baza, 8 (1980), pp. 245-246.

60. ACCV, fondo interno, LE 1.1, fol. 158V.

61. Benito DoméneCH, Fernando: La arquitectura del Colegio del Patriarca... p. 207. 


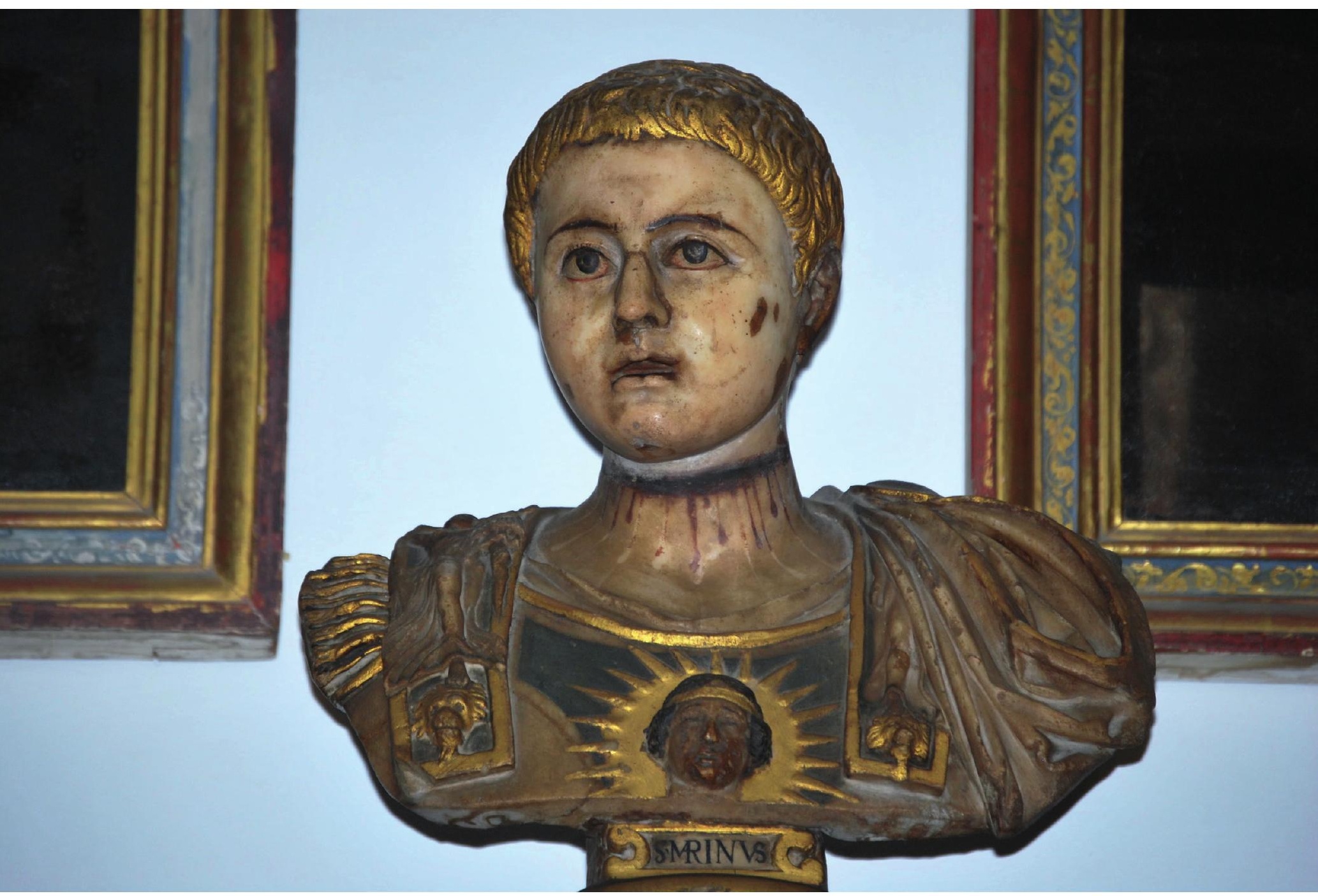

FIGURA 13. BUSTO DE EMPERADOR ROMANO CONVERTIDO EN SAN MARINO

Enfrente de los anteriores y en el lateral izquierdo de la biblioteca, el último de los bustos marmóreos, quizás el más apuesto por sus proporciones, e identificado con una enigmática inscripción szvi que se ha de relacionar con el descrito en uno de los salones del palacio arzobispal «Item. Una media figura de mármol con la cabeza dorada con estas letras szvi y la basis de madera pintada de colores» ${ }^{62}$. (FIGURA I4)

La última pieza sería un busto femenino de piedra, bastante deteriorado, del que no hemos encontrado referencias documentales ni inscripciones que nos ayuden a su identificación. Todos ellos están repintados al óleo, la boca, los ojos y los pómulos, y en dorado los motivos ornamentales de las corazas y de los mantos, además tienen un cerco rojizo, en torno al cuello, de donde caen gotas simulando sangre

62. ACCV, fondo interno, LE 1.1, fol. 142R. 


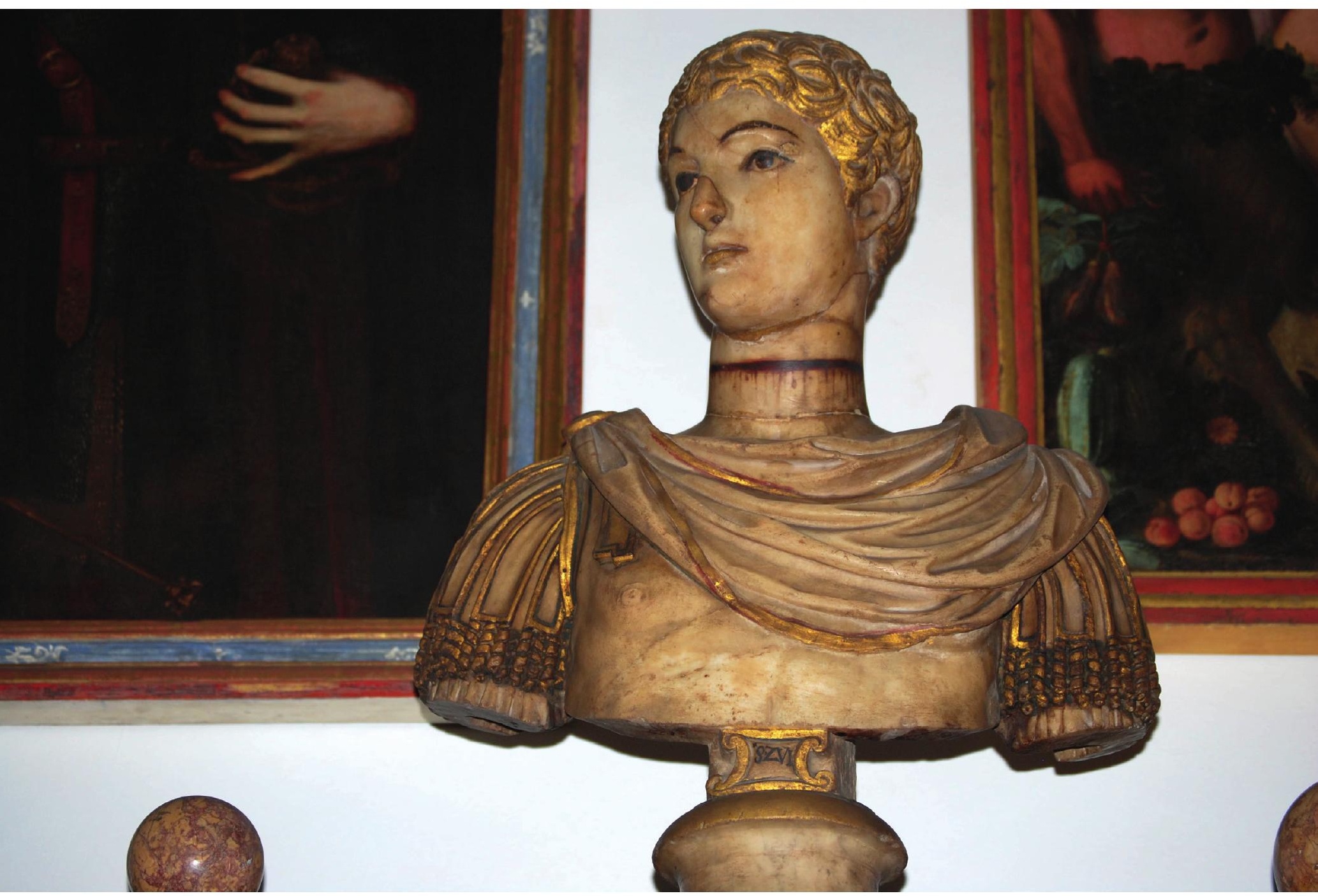

FIGURA 14. BUSTO DE EMPERADOR ROMANO CONVERTIDO EN MÁRTIR CRISTIANO

como si hubiesen sido degollados. En definitiva, unos bustos de clara reminiscencia clásica cristianizados que posiblemente permitió que llegaran hasta nosotros, pero que provocan cierta desazón y curiosidad por lo caricaturesco de los repintes.

Benito Goerlich en un artículo donde profundiza en el pensamiento teológico y espiritual del Patriarca, propone que la influencia de san Carlos Borromeo (I538-I584), arzobispo de Milán y sobre todo de Gabriele Palleoti (I527-I597), arzobispo de Bolonia, con su texto sobre las imágenes sacras De imaginibus sacris et profanis ... libri quinque, editado en latín en $\mathrm{1594}$, pero que Juan de Ribera conoció en su edición resumida de 1582 con el título Discorso intorno alle imagini sacre et profane, posiblemente animara a Juan de Ribera a «revisar» la adquisición de sus obras de arte y sobre todo de la colección escultórica clásica regalada por su padre 
o comprada por él ${ }^{63}$. De hecho, el cardenal Paleotti deplora la costumbre de coleccionar las efigies de personajes paganos como los emperadores romanos, de héroes mitológicos o de filósofos de la Antigüedad, al incluirse entre ellos algunos perseguidores de la Iglesia. Esta reserva que se tenía hacia el arte clásico no era nueva, incluso en Roma, todavía persistía la leyenda de que el Papa Gregorio el Grande había mandado que todas las estatuas más hermosas fueran arrojadas al Tíber a fin de que los hombres, cautivados por su belleza, no fueran inducidos a apartarse de una religión que estaba todavía fresca y reciente, y que fue negada por Andrea Fulvio en 1527 por maliciosamente inexacta. Este enfrentamiento entre la pervivencia del paganismo solapado por la admiración de la belleza y del arte, y la más estricta ortodoxia católica derivó hacia cierta hostilidad estética, púdica y religiosa con la actuación del papa Pío v que llegó a deshacerse de ciertas esculturas del Belvedere y a otras las ocultó con pantallas arquitectónicas para finalmente terminar prohibiendo el acceso a las mismas ${ }^{64}$. También en el ámbito valenciano del siglo Xvı, surgió esta diatriba en los humanistas al utilizarse esculturas y lápidas romanas para cimentar el puente de los Serranos y donde más tarde se destruyeron muchas otras que se encontraban encastradas en los muros de las iglesias por temor a los eventuales riesgos de su contenido gentil ${ }^{65}$.

Esta pugna entre ambas corrientes, sobre todo en la Italia contrarreformista, donde paradójicamente se concentraba la mayor cantidad de escultura antigua pero también era la sede del sucesor de Cristo, sirvió para que ciertos prelados de elevada erudición y de refinado gusto, pero también fieles a la ortodoxia católica tridentina, buscaran soluciones a esta disquisición, la mayor de las veces en su propio interior. Es así, como se entiende que Juan de Ribera transformara algunos de sus muy queridos bustos clásicos en imágenes de mártires cristianos como san Mauro, san Marino o san Acasio que finalmente triunfaron como supervivientes en la religión y en el arte.

Así pues, la propuesta de Benito Goerlich se puede matizar al considerar que Juan de Ribera participó de ambas corrientes. Por una parte tenía que ejercer de miles Christi, al estar comprometido con la ideología tridentina cuyo objetivo prioritario era la protección de los fieles a él encomendados y el de la iglesia universal; pero tampoco pudo olvidar su educación sevillana, refinada, culta y elitista en la Casa de Pilatos, que supo mantener en su casa de Alboraya hasta el final de sus días, comprada con la herencia que le dejó su padre, Per Afán de Ribera virrey de Nápoles, y que finalmente fue vendida junto a tantos objetos suntuarios que había albergado, al nuevo hombre fuerte del rey Felipe 111 , el duque de Lerma ${ }^{66}$. En definitiva, la cultura clásica del Renacimiento donde se había formado y había vivido Juan de Ribera hacía tiempo que había concluido, posiblemente, ni siquiera en su

63. Benito Goerlich, Daniel: «Imágenes para la reforma del arzobispo Juan de Ribera», El Patriarca Ribera y su tiempo. Religión, cultura y política en la Edad Moderna. Valencia, Palacio de Colomina, 2011, CaLLAdo Estela, Emilio (ed.) Valencia, Institució Alfons el Magnànim/Diputació de Valencia, 2012, pp. 609 - 638.

64. HASkelL, Francis \& Penny, Nicholas: El gusto y el arte de la Antigüedad. El atractivo de la escultura clásica (1500-1900). Madrid, Alianza Editorial, 1990, p. 32.

65. Arciniega García, Luis: op. cit. pp.78-82.

66. Benito Doménech, Fernando: Pintura y pintores... p. 203. 
época estas esculturas fueron entendidas, puesto que no existen referencias de cronistas y artistas que visitaran su villa y dejaran testimonios escritos de admiración. El largo siglo xviı se abría con nuevos parámetros religiosos, políticos, artísticos y humanos donde ya no tenía cabida ese mundo. (FIGURA I5)

Como conclusión, el interés de esta colección es doble. Por una parte, dar a conocer una colección de escultura antigua, perteneciente a Juan de Ribera que se ha de encuadrar en un marco erudito y elitista junto a la de otros coleccionistas como el duque de Alcalá, Hurtado de Mendoza y Luís de Ávila; con un marcado gusto personal, donde nuestro protagonista invirtió su peculio en acrecentar su colección y donde la influencia estética de su padre, el i duque de Alcalá, se hace patente, aunque desgraciadamente, la escasez de piezas que restan nos impide tener una imagen de lo que fue, pese a la aportación documental. El otro ámbito es la evolución que tuvo la colección, fruto del cambio religioso, pero también vital de Juan de Ribera a lo largo de su vida, pasando de una extraordinaria colección de escultura antigua a un grupo de obras manieristas de corte tridentino, donde los bustos de emperadores romanos devienen en mártires cristianos, en un interesante proceso evolutivo de las mentalidades, uniendo de forma simbiótica y definitiva el paganismo clásico renacentista con el cristianismo más ortodoxo.

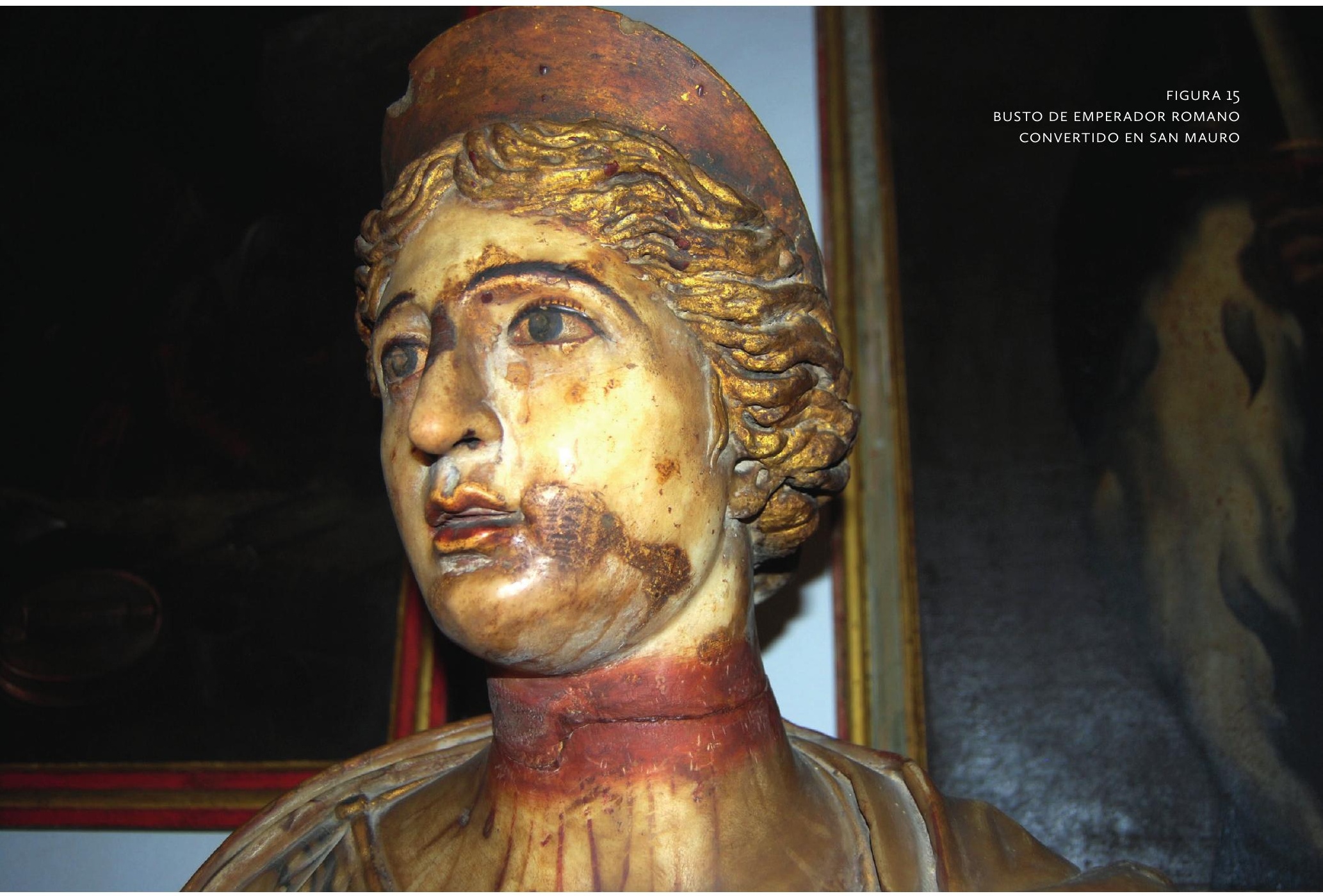




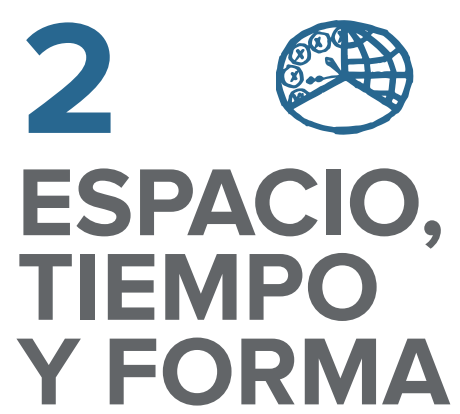

\section{Miscelánea $\cdot$ Miscellany}

David Gimilio Sanz

Poder, humanismo y religiosidad en tiempos del Patriarca Juan de Ribera en Valencia: su colección de escultura clásica / Power, Humanism and Religiosity at the Time of the Patriarch Juan de Ribera in Valencia: his Collection of Classical Sculpture

$$
41
$$

JUAN CRUZ Yábar

De Nápoles a Madrid: la colgadura de los animales del duque de Medina de las Torres / From Naples to Madrid: the Animals Wall Hanging of the Duke of Medina de las Torres

\section{9}

GIOIA ELIA

La etapa italiana de Valentín Carderera (1822-1831) / Valentín Carderera's Italian Sojourn (1822-1831)

\section{María josé Pena García}

Estéticas de lo cotidiano: cuatro visiones de la realidad en la pintura española contemporánea / Every Day Life Aesthetics: Four Visions of Reality in Contemporary Spanish Painting

\section{JuAn José SÁnCHEZ GonzÁlez}

La construcción de un espacio de poder: los castillos del estado señorial de Feria / The Construction of an Space of Power: Castles of the Manorial State of Feria

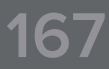

\section{José JaVIer BarRanquero Contento}

La transformación de los modelos arquitectónicos medievales en el Priorato de Uclés: las parroquias de Dosbarrios y Villanueva de Alcardete / The Transformation of the Medieval Architectural Models in the Priorato de Uclés: the Parish Churches of Dosbarrios and Villanueva de Alcardete 